\title{
Article \\ The UNGPs on Business and Human Rights and the Greening of Human Rights Litigation: Fishing in Fragmented Waters?
}

\author{
Liliana Lizarazo-Rodriguez ${ }^{1,2}$ (D) \\ 1 Centre for Environment, Economy and Energy, Brussels School of Governance, Vrij Universiteit Brussel (VUB) \\ Pleinlaan 5, 1050 Brussels, Belgium; Clizaraz@vub.be \\ 2 Law and Development Research Group, Universiteit Antwerpen, 2000 Antwerpen, Belgium
}

check for updates

Citation: Lizarazo-Rodriguez, L. The UNGPs on Business and Human Rights and the Greening of Human Rights Litigation: Fishing in Fragmented Waters?. Sustainability 2021, 13, 10516. https://doi.org/ $10.3390 /$ su131910516

Academic Editor: Olga Martin-Ortega

Received: 2 June 2021

Accepted: 10 September 2021

Published: 22 September 2021

Publisher's Note: MDPI stays neutral with regard to jurisdictional claims in published maps and institutional affiliations.

Copyright: (C) 2021 by the author. Licensee MDPI, Basel, Switzerland. This article is an open access article distributed under the terms and conditions of the Creative Commons Attribution (CC BY) license (https:// creativecommons.org/licenses/by/ $4.0 /)$.

\begin{abstract}
This article is written around the time a Dutch court ordered the corporate group Shell to cut its carbon emissions by 2030. The aim of the article is to contribute to the conceptualisation of the phenomenon this judgement unveils in terms of greening human rights litigation supported by the United Nations Guiding Principles on Business and Human Rights (UNGPs). It addresses, firstly, how claiming the protection of the Earth before courts is occurring in a highly fragmented legal, economic and social context as a way to overcome the multiple obstacles flagged by the literature on the UNGPs. Secondly, it assesses how human rights litigation seeking global justice has evolved in waves with common trends, such as activism from social actors and courts that rely on arguments based on progressive soft law. Thirdly, it identifies two trends in the current wave of green litigation: the anthropocentric perspective that claims the protection of the Earth in the public interest and the ecocentric perspective that claims autonomous rights for Mother Earth. Finally, the article flags some gaps in this third wave of human rights litigation, particularly the risk of disregarding the third pillar of the UNGPs: access to an effective remedy for marginalised communities that are not aware of these ongoing developments.
\end{abstract}

Keywords: ecocentric litigation; public interest litigation; access to remedy; UNGPs

\section{The Broad Context}

In May 2021, a first instance court in The Netherlands rendered a landmark judgement requiring the corporate group Shell to reduce its carbon emissions by $45 \%$ of its 2019 levels by 2030 [1]. It is a landmark judgement because the first instance civil court requires the Dutch parent company to respond for the footprint of the whole corporate group in terms of carbon emissions, based on the corporate responsibility to respect human rights, which corresponds to Pillar II of the UNGPs [2]. However, the legal basis of this decision was the duty of care of the Dutch Civil Code, and the content of the decision was based on the reports from the Intergovernmental Panel on Climate Change (IPCC) that implements the Paris Agreement on Climate Change. Surprisingly, the Dutch court did not consider that this agreement requires member states to apply a differentiated treatment among countries (and of their economic sectors) and to allocate resources for the adaptation process. Neither did the court consider that the Paris Agreement privileges self-regulatory criteria such as the 'highest possible ambition' of states as a due diligence standard to assess environmental risks and take adequate climate measures, cf. [3,4]. Instead, the court imposed rigid targets to reduce carbon emissions in a global value chain (GVC) that is not defined.

This article conceptualises how the current wave of human rights litigation is progressively greening as a way to overcome the obstacles indicated by the literature on the UNGPs. Since the adoption of the UNGPs in 2011, efforts reported in the literature on Business and Human Rights have focused on the possibilities of national, regional, and international courts to address adverse impacts of economic activities. However, the UNGPs fail to address structural gaps in the international legal order to address cross-border conflicts, mainly because of the reluctance of states to recognise international legal personality 
to non-state actors, particularly leading companies of GVCs. This article assesses how new paths, such as climate change litigation, increasingly build their arguments based on human rights issues, rather than on environmental science, to increase the chances of litigating transnationally before courts of home states where leading companies of GVCs are headquartered. However, shifting from the current liability-remedy paradigm towards public interest litigation, or claiming rights of new entities such as future generations or the Earth, might have unclear consequences for marginalised communities. Moreover, ecocentric litigation seems to emerge as a new paradigm. It refers to lawsuits seeking to protect ecosystems directly or indirectly by claiming (collective) environmental rights or rights of nature. It is increasingly used worldwide, as reported by the United Nations Environmental Program (UNEP) [5] (pg. 196).

The greening process of the UNGPs has evolved mainly at two levels. Firstly, global (policy) actors such as the European Union (EU) are progressively enlarging the scope of human rights due diligence to address also environmental risks [6]. Furthermore, the EU Taxonomy Regulation [7] requires companies obliged to report non-financial statements and companies that seek to qualify an investment as environmentally sustainable to comply with the minimum safeguards (Art 18). They are defined as procedures to ensure the alignment with the Organisation for Economic Cooperation and Development (OECD) Guidelines for Multinational Enterprises, the UNGPs, and the principles and rights set out in the eight core conventions of the International Labour Organisation (ILO) and the International Bill of Human Rights. Likewise, the UN working group on Business and Human Rights (UNWG) is arguing for the inclusion of environmental risks into the due diligence procedures that companies are expected to conduct [8].

Secondly, social and ecological movements, including non-governmental organisations (NGOs) and directly interested actors (stakeholders) (SEMS), who have not necessarily been harmed, are strategically lodging claims against states and leading companies of GVCs, not to claim concrete remedies for concrete damages, but rather to represent the general interest in addressing the reported scientific adverse impacts caused by economic activities on ecosystems. These claims are various: human health protection, food security, intergenerational justice and prevention of biodiversity loss, ozone layer depletion, pollution, obstruction of the right to participate in environmental decisions, etc. [9]. Particularly, SEMS increasingly argue that states and drivers of GVCs have not taken effective measures to fight climate change [10] and increase the pressure by enlarging the scope of climate change causes [11,12]. As SEMS are not typically actual victims, they should not demonstrate the causal link between actual damage and the remedy claimed.

The relevance of this article is two-fold. Firstly, it conceptualises the current wave of human rights litigation that is bringing an impressive number of diverse disputes before national, regional, and international courts to claim protection for ecosystems, often connecting ecological conflicts to the duties to respect, protect, and fulfil human rights. It assesses how strategic litigation uses Pillar I and II of the UNGPs but omits Pillar III, which requests the provision of effective remedies for actual victims, who in many cases are vulnerable groups. Secondly, the article unveils the complexity of the context in which human rights litigation is transforming and how this wave is activated by multiple actors and combines multiple factors to nudge policymakers, and to some extent economic actors, to fill ecological governance gaps. However, the outcomes of these proceedings do not necessarily grant effective remedies for actual victims of multiple harms.

The article precisely discusses why the greening process of human rights litigation, particularly based on the UNGPs, should move beyond nudging policymakers and leading companies of GVCs and consider the concrete outcomes for actual victims in terms of access to an effective remedy. It also discusses how SEMS strategically benefit from the complex and fragmented legal, economic, and social contexts. Furthermore, the increasing bargaining power of SEMS, usually led by "transnational" NGOs such as Greenpeace or Clientearth, has positioned them as the representatives of citizens aware of the need to shift the anthropocentric paradigm of the current economic model for a more ecocentric 
approach to preserve ecosystems; but it is unclear who the SEMS are actually representing. These "new" forms of litigation, such as public interest litigation or ecocentric litigation, are "globalising" as a consequence of the globalisation of economic exchanges and of SEMS that benefit from the fragmentation of sustainable development law and its enforcement.

The article concludes that this (third) wave that greens human rights litigation may be more efficient in getting positive outcomes in the courts than the litigation based on Pillar III of the UNGPs. However, this wave disregards what is happening in and with marginalised communities that lack voice and are unaware that SEMS sue in their name to hold states and economic actors accountable.

This article is organised as follows: Section 2 provides the state of the art regarding the fragmented legal, economic, and social spaces in which human rights litigation is greening. Section 3 provides the main methodological framework. Section 4 conceptualises the evolution of human rights litigation in waves with common trends, with emphasis on the greening process of human rights litigation based on the UNGPs. Section 5 discusses the main aspects for future research, particularly the need to revalorise a victims-centred approach, which the UNGPs emphasise in Pillar III but that the greening movement is not directly considering.

\section{State of the Art}

In 2019, the Fundamental Rights Agency of the EU (FRA) [13] empirically assessed the main incidents where EU companies were involved in the framework of the UNGPs in the period 2011-2018. It found that claims seeking environmental protection were the majority. This flags the implicit link between human rights and environmental protection when identifying adverse impacts of economic activities. As noted, International Organisations (IOs) such as the UN and the EU increasingly interconnect environmental and human rights protection [6,8], which has favoured the increasing role of NGOs that claim ecosystems protection, yet frame them mainly in human rights terms. This phenomenon is not new as the framework of corporate social responsibility (CSR), such as the UN Global Compact or the OECD Guidelines for Multinational Enterprises [14], already integrated social and environmental compliance.

UNEP documented how the progressive transformation of environmental litigation is the result of enhancing new forms of litigation to expand access to courts: from the traditional tort and penal procedures to the attribution of responsibility for environmental harms, through claims seeking to avoid future harms, claims in the public interest (of present or future generations), towards claiming rights in the name of nature [5] (pg. 196). Although this transformation seems to be the result of the global awareness of the deterioration of ecosystems that represents a threat to human survival and of the multiple existing obstacles to fill the governance gaps, the academic literature is diverse and covers various disciplines. This part focuses on the fragmented environments where the complexity of the ecological and human rights interplay takes place.

\subsection{The Fragmented Protection of Ecosystems from an International Law Perspective}

So far, no single international instrument systematically addresses the protection of ecosystems and related human rights. This contrasts with the UN and regional systems that protect first and second-generation human rights. The greening of human rights also responds to the transformation of environmental law into sustainable development, a complex concept that seeks to capture the interdependence of the development dimensions. The incompatibility between unlimited economic growth and environmental conservation, and between production patterns and the well-being of future generations [15-18], activated the new paradigm of sustainable development, which represents-progress compared to the previous approaches to development, i.e., economic growth and the human rights-based approach to development (HRBAD) [19]. This paradigm claims that economic activities should benefit people and simultaneously protect ecosystems as natural resources are finite. 
Likewise, multilateral environmental agreements (MEAs) have increasingly multiple foci: environmental protection, mitigation and adaptation, and civic engagement in environmental matters, which has been crucial in the progressive adoption of the concept of sustainable development within the UN since the Conferences on the Human Environment (1972) and the Brundtland Commission (1987) [15]. The concept of sustainable development balances social equity, economic growth, and environmental protection, which is known as the 'triple bottom line' $[15,20]$. This is, sustainable development policies should make economic activities compatible with social equity and the preservation of ecosystems [21-24].

Since the 1990s, an impressive amount of binding (and non-binding) instruments have been adopted in response to the increasing global ecological crisis. Among them, the UN Conference on Environment and Development (1992), the Rio Earth Summit, represents a landmark conference because it defined the main paths of sustainable development: climate change [25], protection of ecosystems [26] and sustainable and fair use of biodiversity [27], cf. also [28,29]. At the regional level, the EU, particularly after the adoption of the Treaty of Lisbon, is the most developed regional legal binding framework on sustainable development, regulating environmental protection (in areas such as water, air, nature, waste, noise, and chemicals) and related mechanisms, e.g., sustainable impact assessments, access to environmental information, and civil and criminal liability for environmental damage. These topics have also been regulated by the UN Economic Commission for Europe (UNECE) [30,31]. Nevertheless, claiming remedies for transnational harms whose consequences go beyond national jurisdictions remains a challenge for victims of ecological harm caused by corporate groups cf. [32].

Excluding the framework of MEAs, multiple soft law initiatives have also been adopted. The Rio Declaration [33] that adopted the Principles of Sustainable Development and the Agenda 21 [34] that promotes a global partnership (trade, investment, and development cooperation) compatible with sustainable development, connect environmental protection with human rights, i.e., they aim at protecting ecosystems with an anthropocentric perspective. These documents explicitly incorporate civic engagement in environmental issues and foster increasing recognition and enforcement of the human right to a healthy environment, which constitutes a central pillar for greening human rights litigation. Hence, environmental human rights that emerged from non-binding principles have progressively been recognised by binding rules [35]. At the national level, the right to a healthy environment has been increasingly recognised in more than a hundred countries. In fact, in 1972, only six states recognised the constitutional right to a healthy environment, whereas, in 2017, most of the countries worldwide (except a few states such as The United States (USA) and Canada) constitutionally or legally recognise this right [5]. Furthermore, several agreements explicitly recognise the right to a healthy environment, and some of them protect civic engagement as procedural environmental rights [31,36-39]. This also explains the exponential increase in rights-based environmental litigation [36,40,41]. This is an important progression in terms of litigation, as when the right to a healthy environment was a component of the right to health, according to the World Health Organisation, claiming its protection was an individual action, whereas now, being an independent right increasingly considered as a third generation human right (collective right), its protection is frequently claimed through collective or class actions.

Currently, the scope of sustainable development is formulated by the sustainable development goals (SDGs) agenda. Some authors regret that this agenda adopted an anthropocentric perspective [42,43], although some goals already have some ecocentric perspectives. The SDGs propose the implementation of sustainable practices via a governance model based on goal setting [44], which is revolutionary compared to the hard law regulation tradition that has not been able to protect ecosystems. The SDGs also enlarged the triple bottom line of sustainable development to two new interconnected dimensions: peace and partnership. 
Surprisingly, the UNGPs adopted in 2011 omitted the triple bottom line of sustainable development and only referred to the economic (business) and social (human rights) dimensions. Principle 12 refers to the scope of the corporate responsibility to respect human rights, as contained in the Bill of Human Rights, i.e., "The Universal Declaration of Human Rights and the main instruments through which it has been codified: the International Covenant on Civil and Political Rights and the International Covenant on Economic, Social and Cultural Rights", besides the eight ILO core conventions. Therefore, environmental rights were not considered as part of the Bill of Human Rights. Furthermore, regarding Principle 18 on human rights impact assessments, it clarifies that this assessment can be incorporated, " ( . . ) within other processes such as risk assessments or environmental and social impact assessments", that could be understood as separate topics.

The UNGPs also failed to connect to the 2010 UNEP Guidelines for the development of domestic legislation on liability, response action, and compensation for damage caused by activities dangerous to the environment. The reality shows that even if the UNGPs were not intended for environmental harms, most of the claims lodged against companies headquartered in the EU are framed under the UNGPs but refer to environmental rights [13]. This phenomenon is also visible in climate change litigation, which has been mainly developed in the U.S. [10], where it has often been linked to climate attribution (global warming, greenhouse gas emissions, sea-level rise, etc.) and less to participatory environmental rights or to the right to a healthy environment, not recognised by the U.S. In 2021, UNEP reported enlargement of the topics alleged in the lawsuits of climate change: climate rights, domestic enforcement; corporate liability and responsibility; keeping fossil fuels in the ground; failure to implement adaptation measures; and climate disclosures and greenwashing [10] (pg.14), which connect to the UNGPs mechanisms of corporate responsibility.

Moreover, alignment between the SDGs and the UNGPs has been promoted [45], but there is a concern because corporate responsibility is omitted by the SDGs. At times policymakers and corporate groups choose for sustainability policies aligned with the SDGs rather than implementing the mechanisms of due diligence of the UNGPs [46] (pg.89) [47]. Furthermore, The UN Framework Principles on Human Rights and the Environment (2018) [48] systematised the rules and principles that protect environmental rights, particularly anti-discrimination, access to information, public participation, and reporting environmental impacts. However, these principles omitted any reference to the UNGPs, which shows a lack of coordination among UN agencies dealing with sustainability topics.

This fragmented regulatory framework of sustainable development, and the fragmented regulatory framework of the third generation of human rights (collective rights), are reflected in the fragmentation of their enforcement. As no international court has exclusive jurisdiction to enforce the sustainable development legal framework, state and non-state claimants struggle with how and where to lodge their claims [49-52]. The International Court of Justice (ICJ) has heard some related claims [53-55], as well as the World Trade Organisation (WTO) dispute settlement body that in exceptional landmark cases has referred to non-WTO law and to the policy space states have to protect the environment [56-59]. International arbitration tribunals have also heard investment-related environmental conflicts as some corporations have challenged states' environmental policy space or national judgements that condemn corporations for environmental harm [60-65]. In general, arbitration tribunals privilege investment protection over environmental or human rights protection [66].

Regional courts have also been triggered by victims of ecological harm and stakeholders to claim compensation against member states that have failed to protect them, even if a non-state economic actor is mainly responsible for the harm. So far, the Inter-American Court of Human Rights (ICtHR) has reiteratively protected the environment when protecting the rights of indigenous communities [67-72], and recently an advisory opinion made the right to a healthy environment (considered as a socio-economic right) justiciable in connection with the justiciable character of the San Jose Pact [73,74]. Several academics claimed that the ICtHR recognised, for the first time, the right to a healthy environment [75-77], 
although in the ratio decidendi of the judgement Lhaka Honat v. Argentina, it actually ordered the protection of the right to property of the indigenous community on their ancestral lands and not on the right to a healthy environment. The European Court of Human Rights (ECtHR) has also protected the environment in connection to civil and political rights, and mainly to the rights to life and access to justice [78,79]. In 2020 it admitted a complaint lodged by six Portuguese youth against 33 countries that are violating their human rights to life, privacy, and non-discrimination because they have failed in taking effective action to prevent climate change. The Global Legal Action Network (GLAN) is playing a central role, even if it could not lodge the complaint directly [80]. So far, no cases have been reported before the African Court of Human Rights (ACtHR). At the Court of Justice of the EU (CJEU), environmental issues have been frequent), but environmental rights claims appear mainly after the integration of the EU charter by the Treaty of Lisbon and the ratification of the Aarhus Convention [31,81] (pg. 1605). Regarding public interest litigation, in March 2021, the CJEU dismissed the People's Climate Case initiated by 10 families from several EU member states, Kenya, Fiji, and the Saami Youth Association Sáminuorra [82]. The CJEU unadmitted the claim because the challenged acts do not identify the appellants as being the addressees of those acts, nor were the claimants able to demonstrate a direct and individual concern as required by the Treaty on the Functioning of the European Union (TFEU) (Art 263).

\subsection{The Fragmentation of Global Economic Activities: The Hegemony of GVCs}

The development of the international framework on sustainable development has occurred against the background of the current wave of globalisation of the economy (from the end of the 1980s onwards). The fragmentation of economic activities added complexity to regulating and managing the impacts caused by these economic activities. This fragmentation or 'second great unbundling' of production is the result of technological innovations that reduced costs in communication and transportation, in combination with the liberalisation of trade policies $[83,84]$. The new architectures of transnational production were conceptualised as GVCs [85-87], or 'global production networks' [88-90]. Since then, GVCs have been the focus of attention as their governance and impact on human rights and the environment represent major challenges for regulatory authorities [91-94].

As GVCs imply some degree of vertical coordination [95], long-term commercial relationships and asymmetric power relationships (e.g., between coordinating and subcontracted companies), the old dichotomy between market transactions (between independent companies) and intra-organisational transactions has become blurred. This has likewise challenged the establishment of extra-contractual responsibilities in a GVC context in case of ecological or human rights harms. GVCs cover the transformation and commercialisation of products, but the distribution of benefits inside the chain, and the negative impacts on people and on the planet that they can cause, are still a global challenge [93] (pg. 381).

In 2020, the World Development Report [96] (pg. 119) highlighted that GVCs as main drivers of development are generating mixed effects on ecosystems as they produce adverse impacts; however, technology is helping them to minimise these impacts. An important fact is that GVCs have delocalised industries to jurisdictions that are accused of not enforcing environmental standards in the same way as developed countries. However, the World Bank argues that technology transfer conducted through GVCs spreads more environmentally friendly production in host countries [96]. Although this is true, the reality is that obsolete technologies are mainly delocalised, and in some countries, the subsidiaries operate under weaker environmental and human rights standards.

The UNGPs aim to hold leading companies of the GVCs accountable for enjoying the advantages of delocalising industries but not assuming their responsibilities of working with the same standards imposed in home countries. In the last 10 years, hundreds of articles have focused on the challenges of holding them accountable for human rights adverse impacts caused by their commercial partners, and some states such as France, the U.S. (California), the U.K., The Netherlands, and the EU have adopted binding rules that 
partially adopt the UNGPs [97-100]. However, the liability-remedy bottleneck has not been overcome. How to hold GVCs accountable for their transnational impacts on human rights and ecosystems is still a major challenge for international and national jurisdictions that the UNGPs have not yet solved. More importantly, the fragmentation of production has also developed hand in hand with complex corporate structures and commercial contracts that make it almost impossible to identify clear legal ties and responsibilities. In the case of ecologic harm, the attribution of responsibility is particularly complex as it mainly targets the visible perpetrators; however, they are frequently part of a GVC and, therefore, shared responsibility becomes a complex technical issue beyond the knowledge of lawyers and judges.

The impressively detailed regulation of sustainable development contrasts with the micro-deregulation of GVC activities operating in pluralist legal spaces, which also explains part of the governance gaps [93,94] Moreover, GVCs support self-regulatory schemes, such as the CSR or mechanisms to improve the traceability (audits or compliance mechanisms), which further increases complexity when attributing accountability of GVC participants for adverse impacts on human rights and ecosystems. Although self-regulatory schemes, promoted by the CSR and the UNGPs, are progressively incorporated into binding state rules, the attribution of liability is still the major bottleneck as it mainly targets the visible perpetrator, but frequently, they are part of a GVC whose complex structure represents a major challenge [94-103]. In addition, mechanisms designed for national jurisdictions, such as tort or criminal cases and private international law, appear unsuitable to address fuzzy adverse impacts caused by global economic transactions such as GVCs that operate in multiple and fragmented legal orders [104,105].

Drivers of GVCs progressively adopt self-regulation schemes to increase quality, reputation, consumer acceptance and to respond to global activism without being constrained and forced to comply with it $[106,107]$. SEMS constantly scrutinise GVCs regarding human rights and environmental protection, yet also regarding the lack of synchronisation between economic upgrading and social upgrading [108], which is not addressed by the UNGPs either.

\subsection{The Fragmented Intervention of SEMS}

Increasing social awareness of the current transnational socioecological crises has also resulted in fragmented socioecological activism. SEMS increasingly are fishing in diverse national and regional courts worldwide with diverse arguments in order to nudge policymakers and corporate groups to redress ecological damages, mainly based on human rights norms. The fragmented connection between sustainable development and human rights normative orders at the various levels of governance can explain this fragmented strategic behaviour of SEMS. They increasingly privilege human rights arguments and use the UNGPs rather than the UN framework principles on human rights and the environment. However, they also support their actions in other normative orders composed of hard and soft law to link climate attribution and other ecological harms to human rights abuses and try to attribute these abuses to corporate groups operating transnationally.

SEMS are also increasingly active in countries where collective or solidarity rights, also known as the "third generation" of human rights (on the origin of the concept, cf. [109]), have been explicitly recognised. Collective rights recognition allows affected groups to claim entitlements that they can seldom claim individually [110], such as the right to a healthy environment or civic engagement in environmental issues. Collective rights are part of the concept of sustainable development because its recognition empowers vulnerable groups such as peasants [111] indigenous people [112,113], and in some Latin American countries, these rights have been extended to afro-descendants communities [114]. Consumers and other self-identified groups affected by serious threats such as forced displaced populations due to ecological disasters [115-117] are also increasingly able to lodge collective claims. The international framework on sustainable development has not explicitly recognised collective rights in a systematic way, and national legislations do not empower 
all groups in the same way [18] (pg. 880), which adds complexity to SEMS action. SEMS increasingly claim the protection of ecosystems based in strategic litigation or by claiming the rights of Mother Earth, particularly in countries with indigenous populations such as India, Colombia, New Zealand, or Ecuador. However, some regional trends in SEMS action can be identified.

In Latin America, indigenous groups have been particularly empowered by the ratification of ILO Convention 169 on Indigenous and Tribal People Convention [112] and by progressive constitutions in many countries that have recognised collective rights. In Colombia, for example, collective actions are recurrent to protect the ecosystems in connection to human rights [118]. However, in Latin America, SEMS act under threat. They expect that the Escazú agreement [39] will protect their action, but it still needs to be ratified by half of the signatories, some of them with jurisdiction in key ecosystems such as the Amazon rainforest.

In Europe, civic engagement in environmental matters is well established. SEMS are highly empowered, mainly by the Aarhus Convention [31], which has not been directly applied by the European Court of Human Rights (ECtHR) or by the CJEU. SEMS increasingly target governments through diverse mechanisms: greening human rights claims by challenging laws or environmental licences, or requesting action from states or GVCs leading companies against climate change in the name of the public interest [119], or even of nature [120]. However, SEMS in Europe do not usually invoke collective rights or contact actual victims to estimate actual harms. They are rather strong influencers of public opinion and use the traditional civil norms on tort to denounce states (and companies) that have not taken sufficient measures to implement international and regional binding and non-binding regulations to prevent climate change, which constitutes human rights abuses. Public interest litigation is increasing, but usually, states do not accept this mechanism for claiming concrete remedies. This is the case of recent reforms of public interest litigation in The Netherlands, where since 2020, the Dutch Civil Code (article 3:305 a) allows public interest litigation by collective actions lodged by organisations of general interest if they are "sufficiently representative", interpreted as representing a "large proportion of those affected" [121]. These associations are entitled to represent people unless they opt out and they can claim financial compensation [121]. Belgium also amended the Judicial Code (Art. 17) on public interest litigation that grants standing to legal persons that "Seek to protect human rights or fundamental freedoms recognised in the Constitution and in binding international instruments" to lodge lawsuits. The claim can only refer to the protection of a collective interest but not to specific remedies for victims. Therefore, the current wave of climate change litigation is claiming human rights abuses, but it is focusing on improving the regulatory gaps by adopting concrete binding rules to hold states and GVCs liable for (transnational) ecological harms. It is unclear in whose name SEMS are acting, whether victims feel represented by them, and whether they neglect intermediate ways such as mediation procedures of the OECD National Contact Points or alternative or complementary mechanisms, such as the non-state-based grievance mechanisms offered by GVCs, by funding institutions or by multistakeholder initiatives [122,123].

Consumer groups are part of SEMS, and they have been particularly empowered in the EU and the U.S. through the recognition of class actions to the point that they are the worldwide actors of SDG 12. For instance, consumer groups and stakeholders have sued GVCs or states for authorising and commercialising pesticides. Recent reports from Greenpeace [124] and from the UN Special Rapporteur on toxics requested European industries that export banned toxic chemicals in the EU to poorer nations to finish these practices [125]. The EU Chemicals Strategy for Sustainability [126] reiterates that the toxic-free environment announced in the European Green Deal [127] needs to be materialised in the prohibition on export of dangerous substances, forbidden in the EU, to third countries [46]. In fact, sustainable consumption is considered as a "tipping element" to fight transnational human and ecological harm caused by GVCs, because it can target the finances and the reputation of GVCs [128-131]. They are increasingly scrutinising how companies report on their 
environmental impacts and the green claims that companies make. The disclosure of non-financial information of corporate groups, designed on the basis of CSR rather than on the basis of the UNGPs, which seeks to inform stakeholders how they identify and address actual or potential risks of their operations, including the ones of their partners, has also empowered SEMS. These increasingly binding reporting duties have also been affected by the phenomenon of greenwashing [132-134] that constitutes an additional source of litigation (even under the label of climate change litigation [10]).

SEMS have, therefore, a fuzzy identity and a fragmented modus operandi that challenge the national and international rules on legal standing and the liability-remedy paradigm, mainly by greening human rights claims. This strategy seems to seek to overcome the bottlenecks flagged on the implementation of the UNGPs that claim for more flexible tort rules, extraterritorial jurisdictions, and acceptance of collective claims on remedy that are not systematically accepted by state-based remedy mechanisms.

SEMS have also strategically based their claims on soft law and policy commitments such as the UNGPs and General Comments (GC) of the UN treaty bodies. They have also taken advantage of the central role of stakeholders in the UNGPs and from other non-binding principles to formulate concrete claims against corporate groups and states. However, who they are and how they act are also complex issues of this greening process.

Diverse strategies have been used by SEMS to activate judicial mechanisms to enforce sustainable development and human rights normative orders. Firstly, SEMS request the acceptance of jurisdiction even if the claim may not be admissible because it disregards the principle of separation of powers, state sovereignty in cross-border judicial procedures, or the sphere of competences of courts. Secondly, SEMS require legal recognition of collective rights, which increases pressure on states and on GVCs [135]. Thirdly, SEMS seek to attribute liability to state and non-state actors, in some cases based on the UNGPs, but without a comprehensive analysis on the common but differentiated responsibilities among them [2,136]. Fourthly, SEMS claim measures that are not necessarily foreseen in the legal norms invoked and not necessarily benefiting all actual victims. In climate change litigation, the Paris Agreement, for example, relies on the Warsaw International Mechanism for Loss and Damage to attribute responsibility on climate change that lacks a binding character. However, the Dutch court (the Urgenda case) and the German Constitutional Court are requiring states to adopt concrete targets in line with international standards (Cf. infra).

\section{Methodological Approach}

This article consists of a conceptual exercise seeking to explore how human rights litigation evolved in waves, how litigation based on the UNGPs constitutes such a wave, and how this litigation is greening in a multidimensional fragmented environment. The conceptualisation of this phenomenon, while drawing on the literature on the UNGPs, seeks to find linkages with other literature dealing with the same issue, i.e., how to hold states and coordinating firms of GVCs accountable for the adverse impacts they cause on ecosystems and on people.

This conceptualisation goes beyond the legal positivist analysis of the UNGPs and is the result of a revision of academic literature, grey literature, and jurisprudence that unveil the fragmentation and interconnection of the contexts involved (normative, economic, and social). Although the analysis is based in the literature on the UNGPs, its scope is larger in order to understand how human rights litigation has evolved before the UNGPs and how these principles are greening, as is also the case with other human rights frameworks.

The focus of the analysis is, therefore, on the identification of the contexts, the processes of greening human rights litigation, the legal bases, and the actors. The literature review, as well as the mapping of salient cases, was conducted from a cross-disciplinary perspective. It does not have the ambition to conduct a detailed jurisprudential analysis of each of the judgements referred to, but rather to map lawsuits lodged with the purposes of protecting ecosystems yet directly or indirectly connected to the UNGPs. 
The review mainly draws on literature from the Business and Human Rights, but also considers the sociology of law [137], behavioural economics [138], environmental justice $[139,140]$ as well as other postmodern approaches to ecological protection (Earth Jurisprudence, cf. below). These areas were selected in order to better understand the contexts (normative, economic, and social) where human rights litigation, mainly based on the UNGPs, is increasingly embedded into the normative framework of sustainable development and even into ecocentric perspectives that challenge the legal positivist approach to human rights and to environmental protection.

\section{Conceptual Analysis}

This section conceptualises, firstly, the common elements of the waves of human rights litigation: social activism, judicial activism based on the progressive adoption of soft law, and governance by goal setting [44]. Secondly, it conceptualises the two main current approaches to the protection of ecosystems that have resulted from the increasing strategic interconnection between environmental and human rights claims, the recognition of environmental rights as individual or collective rights, or hybrid regimes that increasingly grant rights to legal fictions such as future generations or ecosystems. These approaches seem to be the result of governance and regulatory failures because, despite the impressive enactment of national and international hard and soft law, ecosystems deteriorate at worrying levels, and states and GVCs have failed to redress these harms.

\subsection{Greening Human Rights Litigation Is the Third Wave of Human Rights Litigation}

Social activism, judicial activism, and progressive adoption of soft law have been a repetitive formula in claiming rights when policymakers do not take sufficient measures to respect, protect and fulfil human rights. The origin and success of human rights litigation are closely connected to the entry into force of the Bill of Human Rights referred by the UNGPs and the subsequent emergence of the European, Inter-American, African, and, recently, the EU regional human rights systems.

The first wave of human rights litigation seeking global justice can be traced back to the claims for the justiciability of the second generation of rights (economic, social and cultural rights (ESCR)) at the end of the XX Century and beginning of the XXI Century, based on the Declaration on the Right to Development (1986) and a series of GC of the UN Committee on ESCR (CESCR) [141-143]. The justiciability of ESCR rights challenged the traditional separation of powers and judicialised budgetary and social policies, a trend that was globalised [144,145] (pg. 22), [146-151], even in the EU during the crisis of 2008 [152].

The second wave claims to recognise the extraterritorial obligations of states to hold non-state actors (mainly GVCs leading companies, investors, development banks, etc.) accountable beyond their jurisdictions. This wave has been mainly activated by the adoption of the UNGPs that complement the self-regulatory framework of CSR and seek synergies with the regulatory frameworks of trade and investment agreements [153]. Besides the UNGPs, other non-binding standards and guidelines have contributed to the formulation of arguments to request their application by the courts. Moreover, some UN treaty bodies have adopted GCs on state obligations in the context of business activities [154], and on the impact of business on children's rights [155].

SEMS have targeted the role of (developed) states in controlling GVCs that operate in host countries without any (inter)national control and have been involved in serious human rights and environmental harms. However, the UNGPs have not been satisfactorily implemented despite some translations into mandatory rules, mainly in the EU. As noted, even if the UNGPs omitted the environmental dimension, most of the claims framed in terms of transnational accountability of EU companies deal directly or indirectly with ecological harms (mining, land grabbing, water resources, pollution, force displacement, biodiversity loss, deforestation, etc.) [13]. Nevertheless, many bottlenecks have become commonplace in the abundant literature: the limitations of a national tort, administrative, 
criminal, and international private law to obtain effective remedy in cross-border cases (the work of [104,156-160], just to mention a few).

The third and current wave of greening human rights litigation has been activated by an anthropocentric approach, based on the increasing recognition of environmental rights, the Paris Convention on Climate Change, and the SDGs [161]. The scientific reports on the ecological crises have further supported the ecocentric approach to protecting ecosystems. The latter is a postmodern approach that challenges the current economic model, developed mainly by GVCs, to prevent global ecological disasters. This wave is assessed more in detail in the next section.

Briefly, the three waves of human rights litigation have combined these three elements: social activism, court activism, and argumentation based on human rights binding norms and on non-binding norms (soft law). They have unveiled the complexity of the interaction of the fragmented normative, economic and social contexts indicated above. Judicial adjudication in human rights topics deals with complex conflicts that encounter dilemmas and involve multiple (contradictory) interests. These waves of human rights litigation are part of the judicial globalisation that characterises the third globalisation of the law [146] (p. 64), which is also characterised by the globalisation of balancing methods of adjudication. It is also characterised by the mutual citation in human rights matters, which has been considered as the "new ius gentium of human rights" or a viral phenomenon that challenged Legal Formalism [144,162].

These waves of human rights litigation also show that soft law is not innocuous because social activism and judicial activism reach a certain level of effectiveness in nudging the behaviour of policymakers and GVCs actors, thanks not only to the binding legal framework yet also to the strategic use of progressive soft law. They have acquired a viral spread with the potential to nudge policymakers, IOs, and, to a certain degree, economic actors to adapt behaviours. However, this has not necessarily signified effective access to an effective remedy to actual victims of adverse impacts (cf. below).

It is also remarkable that The Netherlands has been an important incubator for this synergy between actors and norms. Dutch academics, together with stakeholders (UN agencies and NGOs), released a series of principles oriented towards the enforcement of ESCR that also shaped the future development of the CESCR GC and case law [163-165]. Dutch academics and stakeholders have also played a central role in the formulation of the extraterritorial obligations in the area of ESCR [166] seeking to control GVCs with respect to ESCR protection. Recently, the judgements rendered by Dutch courts (the Urgenda case [167] and the Shell case [1]) have been considered as trendsetters, although they are not the most innovative from an ecocentric perspective $[119,168]$.

\subsection{From the Anthropocentric Perspective of the UNGPS and the SDGs towards the Eccentric Approach to Claim Rights of Ecosystems}

The strategy of SEMS greening human rights litigation to overcome the reported bottleneck of the implementation of the UNGPs regarding the attribution of responsibility to leading companies of GVCs, deeply documented in the framework of Business and Human Rights, is not concerted nor homogenous. Greening human rights litigation also means that lawsuits increasingly seek to attribute the current ecological crises to the failure of states to comply with the international legal framework on sustainable development and to deficient policy responses and governance gaps with respect to the protection of ecosystems. Most of the claims are increasingly linked, directly or indirectly, with climate change litigation [10]. Climate change litigation is also increasingly framed in line with the UNGPs, in particular regarding the extraterritorial obligations of states and the corporate responsibility to respect human rights along their value chains. However, Pillar III of the UNGPs does not seem to guide these actions, as the legal actions suggest they are strategic in nature. They aim at increasing pressure on policymakers and leading companies of GVCs, independent of the legal and knowledge barriers actual victims encounter to obtain direct access to courts. Therefore, SEMS mainly claim that states and companies must adopt concrete measures to protect the sustainability of ecosystems without necessarily seeking 
concrete remedies for actual (or potential) victims, who are not necessarily consulted. Although this may result in positive actions by governments and corporate groups, SEMS do not necessarily represent victims who are not even aware that they have rights, much less that they can file claims, cf. [137].

In common law countries, such as the U.S., ecological harms have been mainly addressed by using the doctrines of Public Trust and Nuisance. The core idea is that present generations hold the natural resources "in trust for future generations" and, therefore, they are the main duty bearers for the sustainable use of the environment as a public good $[52,169,170]$. In Europe, as it has been mentioned, public interest litigation is the main way human rights litigation is greening. Some landmark cases have been rendered in The Netherlands [1,167], Germany [171], France [172], Belgium [173], and in other countries, the decision is pending. However, the judgement held in May 2021 against Shell [1] is a new landmark case because a national court is holding a corporate group accountable for the carbon emissions of its value chain. The court accepted the standing of NGOs that lodged a collective claim in the general interest of current and future generations from The Netherlands and of the Waddeneilanden. On the contrary, the court rejected the standing of Action Aid that claimed in the general interest of the whole world population and also of the individual claimants. Although it is not the first time a corporate group is held accountable in court for causing transboundary ecological harms, it is the first decision that combines climate change litigation with the UNGPs, and surprisingly it based the source of the legal obligation to conduct due diligence on the duty of care of the civil code. This is a clear victory of SEMS that are increasing their impact on public opinion $[174,175]$. However, as the UNEP reported [10], most of the climate change lawsuits are still lodged in the U.S., where they are not necessarily framed in human rights terms but rather in tort and criminal law terms.

From a conceptual perspective, climate change litigation is a way of greening human rights litigation from an anthropocentric perspective based on the legal framework of sustainable development that links the value of ecosystems to human well-being. The phenomenon has also mainly been assessed from a policy-oriented perspective on the implementation of hard and soft law. Attempts to capture the expansive trend that is increasingly framing any kind of environmental conflict in climate change terms are increasingly documented [10,176-185]. This literature, however, does not conceptualise the phenomenon worldwide beyond the common dichotomy of the global north and global south and tend to ignore legal innovation of many courts worldwide that were trendsetters during the first wave of human rights litigation to enforce ESCR and that now increasingly adopt postmodern ecocentric perspectives [186]. Other authors highlight progress in the "global south" as something new and rare and even identify climate change litigation framed in other terms [187]. Others seek to map these experiences, yet rather from a legal procedural perspective [188].

In contrast, the ecocentric perspective recognises the intrinsic value of ecosystems and adopts a postmodern approach to sustainable development that values ecosystems not only as commodities but also as legal entities with rights in order to guarantee their survival at the benefit of human beings as a species [189-195]. Conceptual frameworks such as "Earth Jurisprudence" [196-199] "Law and Ecology" [200] or "Community Ecological Governance" [201,202] promote this ecocentric perspective. Furthermore, Wild Law [203,204] is the legal area that develops Earth Jurisprudence and aims at wildlife protection. It is not self-identified as part of the legal framework of sustainable development because it rejects the anthropocentric or modern legality perspective that has failed in effectively protecting the integrity of ecosystems [205]. The UN has timidly recognised this approach by means of soft law [206], and SDGs 13,14, and 15 set targets to preserve these ecosystems without linking them directly to human rights. "Global Environmental Constitutionalism" $[195,198,207]$ has identified the evolution from anthropocentric trends in protecting the environment by recognising constitutional collective environmental rights as funda- 
mental rights or by adopting hybrid approaches between human rights and preservation of ecosystems, and explicit ecocentric approaches that grant rights to nature.

Progressive legal systems, such as the one of Ecuador, recognise the constitutional right of Mother Earth and the crime of ecocide, meaning the extensive destruction of ecosystems, such as large-scale land use that causes deforestation, significant pollution, or dangerous industrial activity that destroys ecosystems. It is being advocated to be included in the Statute of Rome of the International Criminal Court (ICC). In June 2021, an expert panel provided a legal definition of ecocide as a crime against humanity, in which environmental scholars, traditionally anthropocentric, developed an ecocentric legal framework [208].

Although the ICtHR [73] recognised the right to a healthy environment by connecting the San Jose Pact and the San Salvador Protocol, yet also held that the enforcement of the Cartagena Convention for the Protection and Development of the Marine Environment in the Wider Caribbean Region, classified as Wild Law, is necessary to preserve human rights. It represents important progress in the integration of Wild Law with human rights, but it also shows that ecocentric approaches before human rights courts still have a long path.

Although ecocentric litigation seems to overcome the barriers flagged in the framework of the UNGPs, notably the attribution of responsibility among corporate groups (piercing the corporate veil) and the acceptance of jurisdiction for transnational complaints, additional bottlenecks, at least from a legal perspective, emerge: firstly, who holds the legal representation of ecosystems? In some cases, any person can claim Earth rights (Ecuador and Bolivia), whereas in other cases, a trustee (usually the state, local communities, or environmental organisations) holds the representation of ecosystems. It is based on the Public Trust doctrine, i.e., the trustee holds ecosystems but must ensure its conservation for future generations $[52,169]$. Moreover, some landmark cases that grant rights to nature have already been rendered in India [209,210], Colombia [118,211,212], and even the East African Court of Justice (EACJ) [213]. Secondly, who has the burden of proof, and what is the applicability of relevant environmental principles such as the precautionary principle, the common but differentiated responsibilities, or rules on impact assessment and licences? This question has not been sufficiently explored yet.

\section{Pending Discussions: The Need for a Multidimensional and Victims-Centred Approach}

Although civil society participation represents an important aspect of the current greening of human rights litigation, SEMS do not necessarily follow the conceptual framework of environmental justice that addresses the ecological debt, conceptually developed mainly by Ecological Economics [139,140,214]. Ecological debt has four dimensions: firstly, debt originated from the intergenerational unfair protection of environmental rights of future generations. Secondly, debt originated by the historical attribution of responsibility for ecological crises and depletion caused by past phenomena such as colonisation $[215,216]$. Thirdly, inter-spatial ecological injustice, i.e., the unequal geographical distribution of ecological risks and adaptation costs and the unequal distribution and unfair exploitation of natural resources among regions $[139,140,217]$. Fourthly, the unfair access to information and justice [218]. Although SEMS adopting ecocentric perspectives seem to protect marginalised communities, it is unclear how affected and marginalised communities are receiving information about their rights [137] and about the greening process of human rights litigation in their names

The Greenpeace Ten Principles for Corporate Accountability (2018) addressed the core challenge of SEMS' legal claims in terms of the UNGPs: states should prevent the GVCs under their control from carrying out activities that threaten the environment or human rights abroad if they are forbidden in their jurisdiction. Moreover, states should provide access to remedy to victims of transnational harms even in their respective jurisdictions. However, this new trend (either anthropocentric or ecocentric) of greening human rights litigation does not seem to focus on access to effective remedies to actual victims. Likewise, SEMS are less concerned with other environmental conflicts such as biodiversity loss or 
unfair commercial practices known as "biopiracy", which refers to the illegal and unfair appropriation of genetic resources and related traditional knowledge without sharing the benefits of their exploitation with local communities $[219,220]$. SEMS, likewise, do not seem concerned about affected persons that result from policies such as degrowth or circular economy.

Looking back at the previous waves of human rights litigation, in the first wave of ESCR justiciability, the effective remedy consisted of the provision by the state of the basic needs to have a dignified life. The concern regarded how activist courts would be able to decide on budgetary and social policies and why they did not consider the scarcity of public resources when granting these rights. The remedy sought in the second wave of human rights litigation, developed in the framework of the UNGPs, has been the availability of (inter)national judicial mechanisms to claim an effective remedy for business-related adverse impacts. The focus has mainly been on how courts can accept jurisdiction and whether they guarantee effective remedies according to the criteria proposed by the UNGPs. From a legal perspective, a case law analysis can provide a certain level of information about the type of remedy granted, but this would depend on the specific jurisdiction or even on a court, which seems a very complex task. An empirical assessment of the compensations provided by the ECtHR flagged the limitations of evaluating case law that grants remedy in human rights violations. The difficulties start with the data collection and with the definition of the types of remedy and its scope, as each remedy can redress or compensate several types of violation of several types of rights. Therefore, the effectiveness of the remedy depends on multiple variables, such as the concrete circumstances, the type of abuse, and the type of right violated that go beyond a legal positivist analysis [122,221].

The few studies on the third wave of human rights litigation have focused on identifying the legal claims (procedures), but the remedies provided are unclear, also because many of these claims are still in course. Contrary to the first and second wave of human rights litigation, claimants of green human rights litigation or of ecocentric claims are not necessarily affected persons or rights holders, and therefore, the complexity of defining the scope of effective remedy increases. If concrete sanctions are the obtained remedy, in many cases, empirical research shows that sanctions for business-related human rights or ecological harms are usually fines, but they did not provide redress for gross human rights abuses because they lack deterrent power or public condemnation of the perpetrators [222]. Furthermore, sanctions are not earned by the affected persons but by the states. Non-monetary sanctions can guarantee non-repetition of abuses when reputation is affected or when specific targets are ordered. Structural remedies may nudge GVC leading companies and policymakers, but they do not necessarily represent an effective remedy either [122]. This was the measure ordered recently by the German Constitutional Court. Besides preserving the ecosystems (mainly) for future generations, actual victims suffering from ecological damages or from environmental measures are, in general, not visible in the state where the claims are brought, and even less so in poor countries.

Therefore, the challenges of the second wave of human rights litigation regarding the guarantee of having access to an effective remedy still remain. Moreover, the attribution of responsibilities among the members of the GVC also requires a technical assessment to see whether the measures adopted by courts guarantee just satisfaction for affected persons and whether the measures ordered are efficient to prevent, mitigate or adapt to ecological damage. Although the decisions on climate change litigation are an important way of nudging policymakers and economic actors, this does not mean that all these judgements on climate change attribution or protecting ecosystems effectively collaborate in filling governance gaps and may or may not have a waterfall effect on access to remedy for victims of ecological harm. SEMS are also claiming compensations when they request the protection of ecosystems, yet it remains unclear how they estimate the damages and who will benefit from these compensations. In The Netherlands, for instance, affected persons are only required to opt out, but it is unclear who will benefit from these compensations and how the court calculates the distribution of the amount between present and future 
generations. The judgement held that the affected persons protected were only residents in The Netherlands. As a result, greening human rights litigation is increasing the uncertainty about the concept and scope of effective remedy that already existed under the Pillar III of the UNGPs, and it is even becoming a black box in climate change and ecocentric litigation.

Another challenge for victims is the increasing power of SEMS and its fragmented and non-regulated action. New actors beyond NGOs, such as the World Wildlife Fund or World Bank Global Forest Alliance, are becoming GVCs of this greening activism. Although the victory of this third wave is positive for protecting ecosystems and will seemingly be more effective in holding corporate groups accountable for transnational adverse impacts on human rights and ecosystems, some structurally unfair situations remain. Marginalised communities do not seem to have a voice in the way human rights are greening and may even be negatively affected, as in cases where orders to protect ecosystems have evicted communities. Courts have protected vulnerable communities in some cases, such as in Kenya [223] or Colombia [224], but in other countries, they have been evicted, such as in Uganda [225] or India [226]. Countries depending on targeted commodities such as oil, palm oil, or coal need to search for radically new sources of income for development, as well-intentioned policies such as 'degrowth' are sometimes implemented at the cost of vulnerable populations. For these victims, how and which type of remedy they can claim (obtain) is still a major gap, and how favourable judgements in cross-border conflicts will be enforced remains uncertain as well [122,227]. Moreover, the adverse impacts of climate change on human rights have not been properly analysed [136].

Therefore, two main points need to be on the radar. Firstly, effective access to justice is in itself a fundamental right recognised by the International Human Rights Bill and other regional conventions [31,36] (Art. 47, 51 and 52.3) [39,228] (Art. 6(1), 13, 35, 46). Future research about the concept and scope of the effective remedy is needed. The concept of remedy is used as a synonym of the availability of legal recourses to grant access to justice. It is also used as a synonym of reparation that may consist of restitution (redress), compensations, injunctions, sanctions, or guarantees of non-repetition. Although the remedy as a synonym of remediation is the core content of Pillar III of the UNGPs and of other legal frameworks such as transitional justice, its scope has not been addressed by any binding rule. Only the non-binding, "Basic Principles and Guidelines on the Right to a Remedy and Reparation for Victims of Gross Violations of International Human Rights Law and Serious Violations of International Humanitarian Law." (The Van Boven Bassiouni Principles) have detailed its scope $[46,122,229]$. The literature does not have a clear approach to remedy either, although few authors distinguish between the procedural and the substantive components $[98,230]$ (pg. 7), however, the procedural part, access to justice, is a human right in itself. Therefore, the distinction between access to justice and access to effective remedy seems more adequate [122] (pg. 354).

Secondly, independently of the fora, the attribution of responsibility, particularly in transnational conflicts, is another key legal challenge that requires technical and scientific evidence, such as in climate attribution that needs reports from places where monitoring activities are not realised, as is the case in many developing countries [174,231,232]. How to equally distribute the benefits of clean production worldwide [233] or how to attribute liability in cases of outsourcing carbon emission inside a GVC [234,235], a topic that is central for the implementation of the Shell judgement, needs an assessment beyond the human rights framework. If these aspects are neglected, greening human rights litigation may result in a Dutch disease, a term that became universal in economics to describe the economic problems that states encounter when a specific economic sector (ironically, natural resources exploitation) develops rapidly at the cost of other economic sectors. It has been considered as a paradox because the suitable results of an economic sector can cause adverse impacts on the economy. In this case, the victory of public interest or ecocentric litigation that fights climate change, mainly caused by natural resource exploitations, is positive. However, its implications for actual victims or marginalised communities affected by climate change, but also by environmental policies targeting sourcing countries highly 
dependent on these products, are unclear. The Dutch court ruled for the whole value chain of Shell, but at the benefit of people living in The Netherlands. What can happen in the short term to other communities is not part of their assessment.

\section{Conclusions}

This article sought to contribute to the conceptualisation of human rights litigation and to the understanding of how the third wave is greening human rights to allow collective claims to protect the Earth as a response to persisting legal bottlenecks that prevent holding states and leading companies of GVCs accountable for transnational ecological harms. It is also a response to the fact that 10 years after the adoption of the UNGPs, no concrete results have been realised in terms of holding companies and home states of leading companies accountable for transnational human rights abuses, which in many cases are the result of adverse ecological impacts.

The article also explains how the third wave of human rights litigation, which follows the previous waves that claimed the justiciability of ESCR and the extraterritorial attribution of responsibility of state and non-state actors in business-related human rights abuses, is evolving in a highly fragmented normative, economic and social context. These three waves of human rights litigation result from the synergy of social and judicial activism based on progressive non-binding principles and guidelines (soft law) seeking to nudge policymakers and economic actors to fill governance gaps related to global justice. Innovative legal instruments, such as the use of collective claims in the name of public interest, or artificial constructs such as future generations or Mother Earth as a subject of rights, have been possible in the fragmented orders where courts are operating. Although this can be a positive trend, the consequences for actual victims, particularly marginalised communities in poor countries, are unclear. The current wave that greens human rights litigation respond to the gaps of the UNGPs in environmental matters. However, green human rights litigation needs to assume a victims-centred approach, independently of the procedural limitations of Pillar III of the UNGPs, of public interest actions, or of the good intentions of ecocentric approaches.

Although the dominant literature considers, as innovative, the courts located in Europe (and particularly in The Netherlands), they are not concerned with the world population. Greening human rights, as in the case of the Dutch judgement that orders the Shell corporate group to reduce their carbon emissions, represents an important victory because it holds the group accountable for its value chain, but it also represents a move that not necessarily guarantees alignment with the third pillar of the UNGPs, particularly of marginalised communities that do not have a voice and do not know that SEMS act in their name. The Dutch court highlighted that claiming protection for the world population is not admissible, as they only address concrete effects for present and future citizens from The Netherlands. This is, the responsibility of the Corporate group is to reduce the emission in the whole chain operating worldwide, but the beneficiaries for the court are the citizens from The Netherlands.

Activist courts in other countries such as Colombia, India, South Africa have been adjudicating in favour of vulnerable communities and protecting the planet before the landmark cases from The Netherlands. The third wave of human rights litigation needs to move outside developed countries to overcome another problem of the UNGPs, which focus on bringing claims to courts from home states of leading companies of GVCs that are also the drivers of globalisation, with the argument that courts in host countries are not able to guarantee access to an effective remedy. However, delocalising the claims also represents an obstacle to obtaining effective remedies, particularly for marginalised communities, as it adds complexity and costs to the procedures.

Funding: This research has received funding from the European Research Council (ERC) under the European Union's Horizon 2020 research and innovation programme (grant agreement No. 949690).

Institutional Review Board Statement: Not applicable. 
Informed Consent Statement: Not applicable.

Data Availability Statement: This article is not empirical.

Conflicts of Interest: The author declares no conflict of interest. The funders had no role in the design of the study, in the collection, analyses, or interpretation of data, in the writing of the manuscript, or in the decision to publish the results.

\section{References}

1. Judgement of the Rechtbank Den Haag of 26 May 2021: ECLI:NL:RBDHA:2021:5337 (Dutch Version) and EC2LI:NL:RBDHA:2021: 5339 (English Version). Available online: https://www.rechtspraak.nl/Organisatie-en-contact/Organisatie/Rechtbanken/Rech tbank-Den-Haag/Nieuws/Paginas/Royal-Dutch-Shell-moet-CO2-uitstoot-terugbrengen.aspx (accessed on 30 May 2021).

2. Human Rights Council (A/HRC/17/31). Guiding Principles on Business and Human Rights: Implementing the United Nations "Protect, Respect and Remedy" Framework, Resolution 17/4 of 16 June 2011. Available online: https:/ / www.ohchr.org/Docume nts/Publications/GuidingPrinciplesBusinessHR_EN.pdf (accessed on 1 May 2021).

3. Bodansky, D. The Paris climate change agreement: A new hope? Am. J. Int. Law 2016, 110, 288-319. [CrossRef]

4. Voigt, C.; Ferreira, F. 'Dynamic differentiation': The principles of CBDR-RC, progression and highest possible ambition in the Paris Agreement. Transnatl. Environ. Law 2016, 5, 285-303. [CrossRef]

5. United Nations Environment Programme (UNEP). Environmental Rule of Law: First Global Report; United Nations Environment Programme (UNEP): Nairobi, Kenya, 2019; Available online: https:/ /www.unep.org/resources/assessment/environmental-rule -law-first-global-report (accessed on 30 May 2021).

6. European Parliament. 2020/2129 (INL) 11.9.2020 Draft Report with Recommendations to the Commission on Corporate Due Diligence and Corporate Accountability Committee on Legal Affairs Proposed by the European Parliament. Available online: https://www.europarl.europa.eu/doceo/document/JURI-PR-657191_EN.pdf (accessed on 25 May 2021).

7. Regulation (EU) 2020/852 of the European Parliament and of the Council of 18 June 2020 on the Establishment of a Framework to Facilitate Sustainable Investment, and Amending Regulation (EU) 2019/2088 (OJ L 198, 22.6.2020). Available online: https: / / eur-lex.europa.eu/legal-content/EN/TXT/?uri=CELEX\%3A32020R0852 (accessed on 25 July 2021).

8. The Revised Version of the Draft Treaty (2020) Proposed by the UNWG on Business and Human Rights. Available online: https://www.ohchr.org/Documents/HRBodies/HRCouncil/WGTransCorp/Session6/OEIGWG_Chair-Rapporteur_se cond_revised_draft_LBI_on_TNCs_and_OBEs_with_respect_to_Human_Rights.pdf (accessed on 25 May 2021).

9. Temper, L.; del Bene, D.; Martinez-Alier, J. Mapping the frontiers and front lines of global environmental justice: The EJAtlas. J. Political Ecol. 2015, 22, 255-278. [CrossRef]

10. United Nations Environment Programme (UNEP). Global Climate Litigation Report: 2020 Status Review; United Nations Environment Programme (UNEP): Nairobi, Kenya, 2021; Available online: https:/ / www.unep.org/resources/report/global-climate-litig ation-report-2020-status-review (accessed on 30 May 2021).

11. European Commission. A Clean Planet for All: A European Strategic Long-Term Vision for a Prosperous, Modern, Competitive and Climate Neutral Economy, COM (2018) 773 Final. 2018. Available online: https:/ / eur-lex.europa.eu/legal-content/EN/TXT /PDF/?uri=CELEX:52018DC0773 (accessed on 26 July 2021).

12. Watts, N.; Amann, M.; Ayeb-Karlsson, S.; Belesova, K.; Bouley, T.; Boykoff, M.; Byass, P.; Cai, W.; Campbell-Lendrum, D.; Chambers, J.; et al. The lancet countdown on health and climate change: From 25 years of inaction to a global transformation for public health. Lancet 2018, 391, 581-630. [CrossRef]

13. European Union Agency for Fundamental Rights (EU FRA). Business-Related Human Rights Abuse Reported in the EU and Available Remedies; European Union Agency for Fundamental Rights (EU FRA): Vienna, Austria, 2019. Available online: https:/ / fra.europa .eu/sites /default/files / fra_uploads / fra-2019-business-and-human-rights-focus_en.pdf (accessed on 30 May 2021).

14. Organisation for Economic Cooperation and Development (OECD). OECD Guidelines for Multinational Enterprises; Organisation for Economic Cooperation and Development (OECD): Paris, France, 2011.

15. Meadows, D.H.; Meadows, D.L.; Randers, J.; Behrens III, W.W. The Limits to Growth. A Report for the Club of Rome's Project on the Predicament of Mankind; Universe Books: New York, NY, USA, 1972.

16. Brundtland, G.H.; Khalid, M.; Agnelli, S.; Al-Athel, S.; Chidzero, B. Our Common Future; World Commission on Environment and Development: New York, NY, USA, 1987.

17. Cullet, P. Environment and development the missing link. In International Economic Law. Globalization and Developing Countries; Faundez, J., Tan, C., Eds.; Edward Elgar Publishing: Cheltenham, UK, 2010; pp. 354-378.

18. Lizarazo-Rodriguez, L. Mapping law and development. Indon. J. Int. Comp. L. 2017, 4, 761-896.

19. Lizarazo-Rodríguez, L. Approaches to law and development. In Encyclopedia of Law and Development; Edward Elgar Publishing: Cheltenham, UK, 2021; pp. 11-15.

20. Du Pisani, J.A. Sustainable development-Historical roots of the concept. Environ. Sci. 2006, 3, 83-96. [CrossRef]

21. Ferro, C.; Padin, C.; Høgevold, N.; Svensson, G.; Varela, J.C.S. Validating and expanding a framework of a triple bottom line dominant logic for business sustainability through time and across contexts. J. Bus. Ind. Mark. 2019, 95-116. [CrossRef]

22. Hammer, J.; Pivo, G. The triple bottom line and sustainable economic development theory and practice. Econ. Dev. Q. 2017, 31, 25-36. [CrossRef] 
23. Birkel, H.S.; Müller, J.M. Potentials of industry 4.0 for supply chain management within the triple bottom line of sustainability-A systematic literature review. J. Clean. Prod. 2021, 289, 125612. [CrossRef]

24. Raworth, K. Doughnut Economics: Seven Ways to Think Like a 21st-Century Economist; Chelsea Green Publishing: Chelsea, VT, USA, 2017.

25. The United Nations Framework Convention on Climate Change (1992) and its protocols, complemented by The Paris Agreement on Climate Change (2015). Available online: https: / / unfccc.int/ (accessed on 10 September 2021).

26. The United Nations Convention to Combat Desertification; United Nations: Rio de Janeiro, Brazil, 1992. Available online: https: / / www.unccd.int/ (accessed on 10 September 2021).

27. The United Nations Convention on Biological Diversity; United Nations: Rio de Janeiro, Brazil, 1992. Available online: https: //www.cbd.int/ (accessed on 10 September 2021).

28. The Cartagena Protocol on Biosafety to the UN Convention on Biological Diversity. 2000. Available online: http://bch.cbd.int/protocol. (accessed on 10 September 2021).

29. The Nagoya Protocol on Access to Genetic Resources and the Fair and Equitable Sharing of Benefits Arising from their Utilization to the Convention on Biological Diversity. 2011. Available online: https:/ / www.cbd.int/abs / (accessed on 10 September 2021).

30. United Nations Economic Commission for Europe (UNECE). Convention on Environmental Impact Assessment in a Transboundary Context; United Nations: Espoo, Finland, 1991.

31. United Nations Economic Commission for Europe (UNECE). Convention on Access to Information, Public Participation in DecisionMaking and Access to Justice in Environmental Matters; United Nations: Aarhus, Denmark, 2001.

32. Committee on Foreign Affairs. Report on Violation of the Rights of Indigenous Peoples in the World, Including Land Grabbing (2017/2206(INI)); A8-0194/2018, 29 May 2018, (2017/2206(INI)); European Parliament: Brussels, Belgium, 2018. Available online: www.europarl.europa.eu/doceo/document/A-8-2018-0194_EN.pdf (accessed on 30 April 2021).

33. United Nations, Rio Declaration on Environment and Development. Report of The United Nations Conference on Environment and Development, Rio de Janeiro, 3-14 June 1992; United Nations: Rio de Janeiro, Brazil, 1992.

34. United Nations, Agenda 21. United Nations Conference on Environment E Development, Rio de Janeiro, Brazil, 3 to 14 June 1992; United Nations: Rio de Janeiro, Brazil, 1992.

35. Rodriguez-Garavito, C.A. Human right to a healthy environment? Moral, legal and empirical considerations. In The Human Right to a Healthy Environment; Knox, J.H., Pejan, R., Eds.; Cambridge University Press: Cambridge, UK, 2017.

36. European Parliament. Charter of fundamental rights of the European Union. Off. J. Eur. Union (2000/C 364/01). Available online: https:/ / www.europarl.europa.eu/charter/pdf/text_en.pdf (accessed on 10 September 2021).

37. Organization of African Unity. The African Charter on Human and Peoples Rights'; Refworld: Banjul, Gambia, 1986; (Adopted 27 June 1981, OAU Doc. CAB/LEG/67/3 rev. 5, 21 I.L.M. 58 (1982). Available online: http://hrlibrary.umn.edu/instree/z1afchar.htm (accessed on 10 September 2021).

38. Organization of American States, Additional Protocol to the American Convention on Human Rights in the Area of Economic, Social and Cultural Rights "Protocol of San Salvador" (1988), San Salvador, El Salvador. Available online: http:/ / www.cidh.oas.o rg/basicos/english/basic5.prot.sn\%20salv.htm (accessed on 10 September 2021).

39. United Nations Economic Commission for Latin America and the Caribbean (ECLAC). Regional Agreement on Access to Information, Public Participation and Justice in Environmental Matters in Latin America and the Caribbean; United Nations: Escazú, Costa Rica, 2018.

40. Jeffords, C.; Minkler, L. Do constitutions matter? The effects of constitutional environmental rights provisions on environmental outcomes. Kyklos 2016, 69, 294-335. [CrossRef]

41. Wood, M.C.; Woodward IV, C.W. Atmospheric trust litigation and the constitutional right to a healthy climate system: Judicial recognition at last. Wash. J. Environ. Law Policy 2016, 6, 634.

42. Kotzé, L.J.; French, D. The anthropocentric ontology of international environmental law and the Sustainable Development Goals: Towards an ecocentric rule of law in the Anthropocene. Glob. J. Comp. Law 2018, 7, 5-36. [CrossRef]

43. Adelman, S. Beyond development: Towards sustainability and climate justice in the Anthropocene. In The Limits of Law and Development; Routledge: London, UK, 2020; pp. 54-72.

44. Biermann, F.; Kanie, N.; Kim, R.E. Global governance by goal-setting: The novel approach of the UN Sustainable Development Goals. Curr. Opin. Environ. Sustain. 2017, 26, 26-31. [CrossRef]

45. Buhmann, K.; Jonsson, J.; Fisker, M. Do no harm and do more good too: Connecting the SDGs with business and human rights and political CSR theory. Corp. Gov. Int. J. Bus. Soc. 2019, 19, 389-403. [CrossRef]

46. Huyse, H.; Lizarazo Rodriguez, L.; Verbrugge, B.; Hoex, L. Report: NBA on Business and Human Rights, Project Commissioned by the Federal Institute for Sustainable Development and the Ministry of Foreign Affairs (Belgium). 2021. Available online: https://nationalbaselineassessment.be/publications/final-report-of-the-nba-on-business-hr/ (accessed on 20 April 2021).

47. Ruggie, J.G. Making Globalization Work for All: Achieving the SDGs Through Business Respect for Human Rights. 2016. Available online: http:/ / www.shiftproject.org/resources/viewpoints/globalization-sustainable-development-goalsbusinessrespect-human-rights/ (accessed on 25 July 2021).

48. United Nations Human Rights Council. Report of the Special Rapporteur on the Issue of Human Rights Obligations Relating to the Enjoyment of a Safe, Clean, Healthy and Sustainable Environment; A/HRC/37/59, 24 January 2018; United Nations: Geneva, Switzerland, 2018. Available online: https:/ / undocs.org/en/A/HRC/37/59 (accessed on 10 September 2021). 
49. Shelton, D. Legitimate and necessary: Adjudicating human rights violations related to activities causing environmental harm or risk. J. Hum. Rights Environ. 2015, 6, 139-155. [CrossRef]

50. Voigt, C. (Ed.) International Judicial Practice on the Environment: Questions of Legitimacy; Cambridge University Press: Cambridge, UK, 2019.

51. Shelton, D. Whiplash and backlash-reflections on a human rights approach to environmental protection. Santa Clara J. Int. Law 2015, 13, 11.

52. Shelton, D.; Kiss, A.C. Judicial Handbook on Environmental Law; United Nations Environment Programme (UNEP)/Earthprint: Nairobi, Kenya, 2005. Available online: https://www.elaw.org/system/files/UNEP.judicial.handbook.enviro.law_.pdf (accessed on 28 July 2021).

53. International Court of Justice (ICJ). Nuclear Test (New Zealand v. France). Available online: https://www.icj-cij.org/en/case/59 (accessed on 1 September 2021).

54. International Court of Justice (ICJ). Pulp Mills on the River Uruguay (Argentina v. Uruguay). Available online: https://www.icj-cij. org/en/case/135/judgments (accessed on 1 September 2021).

55. International Court of Justice (ICJ). Rio San Juan (Costa Rica v. Nicaragua) and (Nicaragua v. Costa Rica). Available online: https:/ / www.icj-cij.org/en/case/152 (accessed on 1 September 2021).

56. World Trade Organisation Dispute Settlement Body—WTO—DS 400: EC—Seal Products. Available online: https://www.wto.or g/english/tratop_e/dispu_e/cases_e/ds400_e.htm (accessed on 1 September 2021).

57. World Trade Organisation Dispute Settlement Body—WTO—DS58: US—Shrimp. Available online: https://www.wto.org/englis h/tratop_e/dispu_e/cases_e/ds58_e.htm (accessed on 1 September 2021).

58. De Bièvre, D.; Espa, I.; Poletti, A. No iceberg in sight: On the absence of WTO disputes challenging fossil fuel subsidies. Int. Environ. Agreem. Politics Law Econ. 2017, 17, 411-425. [CrossRef]

59. Harris, R.; Moon, G. GATT article XX and human rights: What do we know from the first 20 years? Melb. J. Int. Law 2015, 16, 432-483.

60. United Nations Commission on International Trade Law (UNCITRAL). PCA Case 2009-23. Chevron Co and Texaco Petroleum Co v. Ecuador; United Nations Commission on International Trade Law (UNCITRAL). Available online: https://www.italaw.com/cas es/257 (accessed on 1 September 2021).

61. International Centre for Settlement of Investment Disputes (ICSID). Case No. ARB/16/41. Eco Oro Minerals Corp. v. Colombia. Available online: https:/ / www.italaw.com/cases/6320 (accessed on 1 September 2021).

62. International Centre for Settlement of Investment Disputes (ICSID). Case ARB/12/14 2012. Churchill Mining PLC v. Republic of Indonesia. Available online: https:/ / www.italaw.com/cases/1479 (accessed on 1 September 2021).

63. International Centre for Settlement of Investment Disputes (ICSID). Case ARB/12/12. Vattenfall AB and others v. Germany. Available online: https: / / www.italaw.com/cases/1654 (accessed on 1 September 2021).

64. International Centre for Settlement of Investment Disputes (ICSID). Case ARB/07/26. Urbaser, S.A. and others v. Argentine. Available online: https: / / www.italaw.com/cases/1144 (accessed on 10 September 2021).

65. International Centre for Settlement of Investment Disputes (ICSID). Case No. ARB/08/6. Perenco Ecuador Ltd. v. Republic of Ecuador and Empresa Estatal Petróleos del Ecuador (Petroecuador). Available online: https://www.italaw.com/cases/819 (accessed on 1 September 2021).

66. Eberhardt, P.; Olivet, C. Modern pirates: How arbitration lawyers help corporations seize national assets and limit state autonomy. Am. J. Econ. Sociol. 2018, 77, 279-329. [CrossRef]

67. Inter-American Court of Human Rights (ICtHR). Mayagna (Sumo) Awas Tingni Community Case v. Nicaragua. 2001. Available online: https:/ / www.corteidh.or.cr/docs/casos/articulos/seriec_79_ing.pdf (accessed on 10 September 2021).

68. Inter-American Court of Human Rights (ICtHR). Yakye Axa Vs. Paraguay. 2005. Available online: https://www.corteidh.or.cr/cor teidh/docs/casos/articulos/seriec_125_ing.pdf (accessed on 1 September 2021).

69. Inter-American Court of Human Rights (ICtHR). Sawhoyamaxa Vs. Paraguay. 2006. Available online: https://www.corteidh.or.cr /docs/casos/articulos/seriec_146_ing.pdf (accessed on 1 September 2021).

70. Inter-American Court of Human Rights (ICtHR). Saramaka People v. Suriname. 2007. Available online: https://www.corteidh.or.cr /docs/casos/articulos/seriec_172_ing.pdf (accessed on 1 September 2021).

71. Inter-American Court of Human Rights (ICtHR). Claude Reyes et al. v. Chile. 2006. Available online: https://www.corteidh.or.cr /docs/casos/articulos/seriec_151_ing.pdf (accessed on 1 September 2021).

72. Inter-American Court of Human Rights (ICtHR). Kichwa Indigenous People of Sarayaku v. Ecuador. 2012. Available online: https:/ / corteidh.or.cr/docs/casos/articulos/seriec_245_ing.pdf (accessed on 1 September 2021).

73. Inter-American Court of Human Rights (ICtHR). Advisory Opinion OC-23/17. 2017. Available online: https://www.corteidh.or.cr /docs/opiniones/seriea_23_ing.pdf (accessed on 1 September 2021).

74. Inter-American Court of Human Rights (ICtHR). Lhaka Honat v. Argentina. 2020. Available online: https://www.corteidh.or.cr/d ocs/casos/articulos/seriec_400_ing.pdf (accessed on 1 September 2021).

75. Konuk Sommer, B. A new approach to the relationship between environment and human rights: Inter-American court of human rights advisory opinion OC-23/17. Inonu UL Rev. 2020, 11, 384. 
76. Marciante, M. The right to a healthy environment under the ACHR: An unprecedent decision of the Inter-American Court of Human Rights. DPCE Online 2020, 43, 2293-3003. Available online: http://www.dpceonline.it/index.php/dpceonline/article/v iew /1034/1008 (accessed on 25 May 2021).

77. Peñafiel, J.J.F.; Caldera, C.C.; Sánchez, P.P.S. La Corte Interamericana de Derechos Humanos. Hermenéutica del derecho al medio ambiente sano, a la identidad cultural ya la consulta, a la luz de la sentencia "Lhaka Honhat (nuestra tierra) vs. Argentina". Rev. Bras. Políticas Públicas 2020, 10, 644-675. Available online: https://publicacoes.uniceub.br/RBPP/article/view/6764/pdf (accessed on 15 April 2021).

78. Krstić, I.; Čučković, B. Procedural aspects of article 8 of the ECHR in environmental cases: The greening of human rights law. Anal. Pravnog Fak. U Beogr. 2015, 63, 170-189. [CrossRef]

79. European Court of Human Rights (ECtHR). Factsheet-Environment and the ECHR. 21 April 2021. Available online: https: //www.echr.coe.int/documents/fs_environment_eng.pdf (accessed on 10 September 2021).

80. European Court of Human Rights (ECtHR). Duarte Agostinho and Others v. Portugal and 32 Other States. Available online: http:/ / climatecasechart.com/climate-change-litigation/non-us-case/youth-for-climate-justice-v-austria-et-al/ (accessed on 1 September 2021).

81. Hilson, C. The visibility of environmental rights in the EU legal order: Eurolegalism in action? J. Eur. Public Policy 2018, 25, 1589-1609. [CrossRef]

82. Court of Justice of the European Union-CJEU C-565/19. Armando Carvalho and Others vs. European Parliament and Council of the EU Supported by the European Commission. Available online: https:/ / eur-lex.europa.eu/legal-content/EN/TXT/?uri=CELEX: 62019CN0565 (accessed on 10 September 2021).

83. Baldwin, R. The Great Convergence, Information Technology and the New Globalisation; Harvard University Press: Cambridge, MA, USA, 2016.

84. Organisation for Economic Co-operation and Development (OECD). Interconnected Economies: Benefiting from Global Value Chains; OECD Publishing: Paris, France, 2013. [CrossRef]

85. Gereffi, G.; Humphrey, J.; Kaplinsky, R.; Sturgeon, T.J. Introduction: Globalisation, value chains and development. IDS Bull. 2001, 32, 1-8. [CrossRef]

86. Gereffi, G.; Humphrey, J.; Sturgeon, T. The governance of global value chains. Rev. Int. Political Econ. 2005, 12, 78-104. [CrossRef]

87. Gereffi, G.; Fernandez-Stark, K. Global Value Chain Analysis: A Primer; Center on Globalization, Governance \& Competitiveness (CGGC), Duke University: Durham, NC, USA, 2011.

88. Coe, N.M.; Dicken, P.; Hess, M. Global production networks: Realizing the potential. J. Econ. Geogr. 2008, 8, 271-295. [CrossRef]

89. Henderson, J.; Dicken, P.; Hess, M.; Coe, N.; Yeung, H.W. Global production networks and the analysis of economic development. Rev. Int. Polit. Econ. 2002, 9, 436-464. [CrossRef]

90. Porter, M.E. Competitive Advantage: Creating and Sustaining Superior Performance; The Free Press (Macmillan Inc.): New York, NY, USA, 1985

91. Eckhardt, J.; Poletti, A. Introduction: Bringing institutions back in the study of global value chains. Glob. Policy 2018, 9, 5-11. [CrossRef]

92. Salminen, J.; Rajavuori, M. Transnational sustainability laws and the regulation of global value chains: Comparison and a framework for analysis. Maastricht J. Eur. Comp. Law 2019, 26, 602-627. [CrossRef]

93. Turner, B. Supply-chain legal pluralism: Normativity as constitutive of chain infrastructure in the Moroccan argan oil supply chain. J. Leg. Plur. Unoff. Law 2016, 48, 378-414. [CrossRef]

94. Baars, G. IGLP Law and Global Production Working Group. The role of law in global value chains: A research manifesto. Lond. Rev. Int. Law 2016, 4, 57-79. [CrossRef]

95. De Backer, K.; de Lombaerde, P.; Iapadre, L. Analyzing global and regional value chains. Int. Econ. 2018, 153, 3-10. [CrossRef]

96. World Bank. World Development Report 2020: Trading for Development in the Age of Global Value Chains; World Bank: Washington, DC, USA, 2020. Available online: https:/ / www.worldbank.org/en/publication/wdr2020 (accessed on 15 May 2021).

97. Smit, L.; Holly, G.; McCorquodale, R.; Neely, S. Human rights due diligence in global supply chains: Evidence of corporate practices to inform a legal standard. Int. J. Hum. Rights 2021, 25-6, 1-29.

98. Methven O'Brien, C.; Martin-Ortega, O. Briefing 2-EU human rights due diligence legislation: Monitoring, enforcement and access to justice for victims. In Human Rights Due Diligence Legislation-Options for The EU; Policy Department for External Policies, Directorate General for External Policies of the Union: Brussels, Belgium, 2020.

99. Krajewski, M.; Faracik, B. Briefing 1-Substantive elements of potential legislation on human rights due diligence. In Human Rights Due Diligence Legislation - Options for the EU; Policy Department for External Policies, Directorate General for External Policies of the Union: Brussels, Belgium, 2020.

100. Bueno, N.; Bright, C. Implementing human rights due diligence through corporate civil liability. Int. Comp. Law Q. 2020, 69, 789-818. [CrossRef]

101. Boström, M.; Jönsson, A.M.; Lockie, S.; Mol, A.P.; Oosterveer, P. Sustainable and responsible supply chain governance: Challenges and opportunities. J. Clean. Prod. 2015, 107, 1-7. [CrossRef]

102. Vastardis, A.Y.; Chambers, R. Overcoming the corporate veil challenge: Could investment law inspire the proposed business and human rights treaty? Int. Comp. Law Q. 2018, 67, 389-423. [CrossRef] 
103. Aseeva, A. Développements récents en matière de protection des droits fondamentaux et de l'environnement dans les chaînes globales de valeur (recent developments relating to the protection of fundamental rights and the environment in global value chains). In Droits de L'Homme et Droit International Économique; Titi, C., Ed.; Bruylant: Brussels, Belgium, 2019 ; pp. 52-82.

104. Wagner, G. Tort law and human rights. In Transnational Legal Activism in Global Value Chains: The Ali Enterprises Factory Fire and the Struggle for Justice; Saage-Maaß, M., Zumbansen, P., Bader, M., Shahab, P., Eds.; Interdisciplinary Studies in Law; Springer: Cham, Switzerland, 2021; Volume 6, pp. 209-236.

105. Eckert, J.; Knöpfel, L. Legal responsibility in an entangled world. J. Leg. Anthropol. 2020, 4, 1-16. [CrossRef]

106. Singh, K.; Misra, M. Linking corporate social responsibility (CSR) and organizational performance: The moderating effect of corporate reputation. Eur. Res. Manag. Bus. Econ. 2021, 27, 100-139. [CrossRef]

107. Pham, H.S.T.; Tran, H.T. CSR disclosure and firm performance: The mediating role of corporate reputation and moderating role of CEO integrity. J. Bus. Res. 2020, 120, 127-136. [CrossRef]

108. Barrientos, S.; Gereffi, G.; Rossi, A. Economic and social upgrading in global production networks: Developing a framework for analysis. Int. Labor Rev. 2010, 150, 319-340. [CrossRef]

109. Alston, P. A third generation of solidarity rights: Progressive development or obfuscation of international human rights law? Neth. Int. Law Rev. 1982, 29, 307-322. [CrossRef]

110. McIntyre-Mills, J.; Romm, N.; Corcoran-Nantes, Y. (Eds.) Balancing Individualism and Collectivism: Social and Environmental Justice; Springer: Cham, Switzerland, 2017.

111. UN Declaration on the Rights of Peasants and Other People Working in Rural Areas. 2018. Available online: https://www.gene va-academy.ch/joomlatools-files/docman-files/UN\%20Declaration\%20on\%20the\%20rights\%20of\%20peasants.pdf (accessed on 31 August 2021).

112. International Labour Organisation (ILO). C169-Indigenous and Tribal Peoples Convention; International Labour Organisation (ILO): Geneva, Switzerland, 1989.

113. United Nations Declaration on the Rights of Indigenous Peoples. 2007. Available online: https://www.un.org/development/des a/indigenouspeoples/declaration-on-the-rights-of-indigenous-peoples.html (accessed on 31 August 2021).

114. Organization of American States (OAS). The American Declaration on the Rights of Indigenous Peoples; Organization of American States (OAS): Washington, DC, USA, 2015.

115. Burrows, K.; Kinney, P. Exploring the climate change, migration and conflict nexus. Int. J. Environ. Res. Public Health 2016, 13, 443. [CrossRef] [PubMed]

116. Borges, I.M. Environmental Change, Forced Displacement and International Law: From Legal Protection Gaps to Protection Solutions; Routledge: London, UK, 2018.

117. Brzoska, M.; Fröhlich, C. Climate change, migration and violent conflict: Vulnerabilities, pathways and adaptation strategies. Migr. Dev. 2016, 5, 190-210. [CrossRef]

118. Rodríguez-Garavito, C. Human rights: The global south's route to climate litigation. Am. J. Int. Law 2020, 114, 40-44. [CrossRef]

119. Van Geel, O. Urgenda and beyond: The past, present and future of climate change public interest litigation. Maastricht Univ. J. Sustain. Stud. 2017, 3, 56-72.

120. Schoukens, H. Rights of Nature in the European Union: Contemplating the Operationalization of an Eco-Centric Concept in an Anthropocentric Environment? In Non-Human Nature in World Politics. Frontiers in International Relations; Pereira, J., Saramago, A., Eds.; Springer: Cham, Switzerland, 2020; pp. 205-234. [CrossRef]

121. Spijkers, O. Public Interest Litigation Before Domestic Courts in The Netherlands on the Basis of International Law: Article 3:305a Dutch Civil Code. 2020. Available online: https:/ /www.ejiltalk.org/public-interest-litigation-before-domestic-courts-in-the-ne therlands-on-the-basis-of-international-law-article-3305a-dutch-civil-code/ (accessed on 20 April 2021).

122. Lizarazo-Rodríguez, L. The UN 'Guiding principles on business and human rights': Methodological challenges to assessing the third pillar: Access to effective remedy. Nord. J. Hum. Rights 2018, 36, 353-370. [CrossRef]

123. Kaufman, J.; McDonnell, K. Community-driven operational grievance mechanisms. Bus. Hum. Rights J. 2016, 1, 127-132. [CrossRef]

124. Unearthed-Greenpeace. Thousands of Tonnes of Banned Pesticides Shipped to Poorer Countries from British and European Factories. Available online: https://unearthed.greenpeace.org/2020/09/10/banned-pesticides-eu-export-poor-countries / (accessed on 30 April 2021).

125. United Nations Special Rapporteur on Toxics. States Must Stop Exporting Unwanted Toxic Chemicals to Poorer Countries, Says UN Expert. Available online: https://www.ohchr.org/EN/NewsEvents/Pages/DisplayNews.aspx?NewsID=26063\&LangID=E (accessed on 30 April 2021).

126. European Commission. Chemicals Strategy. The EU's Chemicals Strategy for Sustainability Towards a Toxic-Free Environment. 14 October 2020. Available online: https:/ / ec.europa.eu/environment/strategy/chemicals-strategy_en (accessed on 25 April 2021).

127. European Green Deal. Available online: https://ec.europa.eu/info/strategy/priorities-2019-2024/european-green-deal_en (accessed on 31 August 2021).

128. Sunstein, C.R. Behavioural economics, consumption and environmental protection. In Handbook of Research on Sustainable Consumption; Edward Elgar Publishing: Cheltenham, UK, 2015; pp. 313-327. 
129. Fezzigna, P.; Borghesi, S.; Caro, D. Revising emission responsibilities through consumption-based accounting: A European and post-Brexit perspective. Sustainability 2019, 11, 488. [CrossRef]

130. Caro, D.; Pulselli, F.M.; Borghesi, S.; Bastianoni, S. Mapping the international flows of GHG emissions within a more feasible consumption-based framework. J. Clean. Prod. 2017, 147, 142-151. [CrossRef]

131. Mangla, S.K.; Govindan, K.; Luthra, S. Prioritizing the barriers to achieve sustainable consumption and production trends in supply chains using fuzzy Analytical Hierarchy Process. J. Clean. Prod. 2017, 151, 509-525. [CrossRef]

132. De Freitas Netto, S.V.; Sobral, M.F.F.; Ribeiro, A.R.B.; da Luz Soares, G.R. Concepts and forms of greenwashing: A systematic review. Environ. Sci. Eur. 2020, 32, 1-12. [CrossRef]

133. Szabo, S.; Webster, J. Perceived greenwashing: The effects of green marketing on environmental and product perceptions. J. Bus. Ethics 2021, 71, 719-739. [CrossRef]

134. Heras-Saizarbitoria, I.; Boiral, O.; Diaz de Junguitu, A. Environmental management certification and environmental performance: Greening or greenwashing? Bus. Strategy Environ. 2020, 29, 2829-2841. [CrossRef]

135. Fitzpatrick, B.T. Do class actions deter wrongdoing? In The Class Action Effect; Piché, C., Ed.; Éditions Yvon Blais: Montreal, QC, Canada, 2018; pp. 181-203.

136. Humphreys, S. Competing claims: Human rights and climate harms. In Environmental Rights; Routledge: London, UK, 2017; pp. 159-190.

137. Felstiner, W.L.; Abel, R.L.; Sarat, A. The emergence and transformation of disputes: Naming, blaming, claiming. Law Soc. Rev. 1980, 1, 631-654. [CrossRef]

138. Sunstein, C.R. The ethics of nudging. Yale J. Reg. 2015, 32, 413-450. [CrossRef]

139. Martinez-Alier, J. Alier, J. A guide to environmental justice movements and the language of ecological distribution conflicts. In Routledge Handbook of Ecological Economics; Routledge: London, UK, 2017; pp. 162-172.

140. Martinez-Alier, J. Ecological distribution conflicts and the vocabulary of environmental justice. In Ecology, Economy and Society; Springer: Singapore, 2018; pp. 187-204.

141. Committee on Economic, Social and Cultural Rights (CESCR). General Comment 3/1990. Available online: https:/ / www.refwor ld.org/pdfid/4538838e10.pdf (accessed on 1 September 2021).

142. Committee on Economic, Social and Cultural Rights (CESCR). General Comment GC 9/1998. Available online: https:/ www.re fworld.org/docid/47a7079d6.html (accessed on 1 September 2021).

143. Committee on Economic, Social and Cultural Rights (CESCR). General Comment GC 31/2004. Available online: https: //www.ohchr.org/EN/Issues/Education/Training/Compilation/Pages/c)GeneralCommentNo31TheNatureoftheGeneralLega lObligationImposedonStatesPartiestotheCovenant(2004).aspx (accessed on 1 September 2021).

144. Stone Sweet, A.; Mathews, J. Proportionality balancing and global constitutionalism. Columbia J. Transnatl. Law 2008, 47, 72-164.

145. Kennedy, D. Three globalizations of law and legal thought: 1850-2000. In The New Law and Development: A Critical Appraisal; Trubek, D.M., Santos, A., Eds.; Cambridge University Press: Cambridge, UK, 2006; pp. 19-73.

146. Bonilla Maldonado, D. (Ed.) Constitutionalism of the Global South: The Activist Tribunals of India, South Africa, and Colombia; Cambridge University Press: Cambridge, UK, 2013.

147. Gargarella, R.; Roux, T. Courts and Social Transformation in New Democracies: An Institutional Voice for the Poor? Routledge: London, UK, 2017.

148. Landau, D. The reality of social rights enforcement. Harv. Int. Law J. 2012, 53, 189-247.

149. Lizarazo-Rodríguez, L. Constitutional adjudication in Colombia: Avant-garde or case law transplant? A literature review. Estud. Socio-Jurídicos 2011, 13, 145-182.

150. Kibet, E.; Fombad, C. Transformative constitutionalism and the adjudication of constitutional rights in Africa. Afr. Hum. Rights Law J. 2017, 17, 340-366. [CrossRef]

151. Contiades, X.; Fotiadou, A. Social rights in the age of proportionality: Global economic crisis and constitutional litigation. Int. J. Const. Law 2012, 10, 660-686. [CrossRef]

152. Violante, T. The Portuguese Constitutional Court and its austerity case law. In Political Institutions and Democracy in Portugal; Palgrave Macmillan: Cham, Switzerland, 2019; pp. 121-143.

153. De Lombaerde, P.; Kingah, S. (Eds.) Special Issue: EU Free Trade Agreements and Fundamental Rights Protecting Commercial Interests or Exerting Normative Power? Eur. Law J. 2014, 206, 689-713.

154. Committee on Economic, Social and Cultural Rights (CESCR). General Comment 24/2017.E/C.12/GC/24. Available online: www.ohchr.org/EN/NewsEvents/Pages/DisplayNews.aspx?NewsID=21798\&LangID=E (accessed on 1 September 2021).

155. UN Committee on the Rights of the Child General Comment 16/2013 CRC/C/GC/16. Available online: www2.ohchr.org/engli sh/bodies/crc/docs/CRC.C.GC.16.pdf (accessed on 1 September 2021).

156. Addo, M.K. The reality of the United Nations guiding principles on business and human rights. Hum. Rights Law Rev. 2014, 14, 133-147. [CrossRef]

157. Martin-Ortega, O.; Hoekstra, J. Reporting as a means to protect and promote human rights? The EU non-financial reporting directive. Eur. Law Rev. 2019, 44, 622-645.

158. Gibney, M. Litigating transnational human rights obligations. In Challenging Territoriality in Human Rights Law; Routledge: London, UK, 2015; pp. 90-111.

159. Buhmann, K.; Fasterling, B.; Voiculescu, A. Business \& human rights research methods. Nord. J. Hum. Rights 2018, 36, 323-332. 
160. Rodriguez-Garavito, C. (Ed.) Business and Human Rights: Beyond the End of the Beginning; Cambridge University Press: Cambridge, UK, 2017.

161. The Lancet. Progress in environmental litigation, Editorial. Lancet 2017, 389, 21-64.

162. Bomhoff, J. Balancing, the global and the local judicial balancing as a problematic topic in comparative (constitutional) law. Hastings Int. Comp. Law Rev. 2008, 31, 555-586.

163. The Limburg Principles on the Implementation of the ICESCR. 1986. Available online: https://www.ohchr.org/Documents/Publ ications / training12en.pdf (accessed on 1 September 2021).

164. The Maastricht Guidelines on Violations of Economic, Social and Cultural Rights. 1997. Available online: http:/ /hrlibrary.umn. edu/instree/Maastrichtguidelines_.html (accessed on 1 September 2021).

165. van Genugten, W.J.M.; Flinterman, C.; Hunt, P.; Mathews, S.M. Tilburg Guiding Principles on World Bank, IMF and Human Rights. In World Bank, IMF and Human Rights; van Genugten, W.J.M., Hunt, P., Mathews, S.M., Eds.; Wolf Legal Publishers (WLP): Nijmegen, The Netherlands, 2003; pp. 249-257.

166. The Maastricht Principles on Extraterritorial Obligations in the Area of ESCR. 2011. Available online: https://www.etoconso rtium.org/nc/en/main-navigation/library/maastricht-principles/?tx_drblob_pi1\%5BdownloadUid\%5D=23 (accessed on 3 September 2021).

167. The Urgenda Case: The Dutch Supreme Court, Judgment of 20 December 2019 ECLI:NL:HR:2019:2007. Available online: https: / / www.urgenda.nl/wp-content/uploads/ENG-Dutch-Supreme-Court-Urgenda-v-Netherlands-20-12-2019.pdf (accessed on 3 September 2021).

168. Jacometti, V. Climate change litigation: Global trends and critical issues in the light of the Urgenda 2018 decision and the IPCC special report "Global Warming of $1.5^{\circ} \mathrm{C}$ ". Global Jurist 2020, 1. [CrossRef]

169. Dernbach, J.C. The potential meanings of a constitutional public trust. Environ. Law 2015, 45, 463-518.

170. Oakes, A.R. Judicial resources and the public trust doctrine: A powerful tool of environmental protection? Transnatl. Environ. Law 2018, 7, 469-489. [CrossRef]

171. Deutsche Welle. German climate law is partly unconstitutional, top court rules. Deutsche Welle, 21 April 2021. Available online: https:/ / www.dw.com/en/german-climate-law-is-partly-unconstitutional-top-court-rules/a-57369917 (accessed on 3 September 2021).

172. Le Monde. "L'Affaire du Siècle": L'Etat Condamné Pour «Carences Fautives» Dans la Lutte Contre le Réchauffement Climatique. Le Monde, 3 February 2021. Available online: https:/ / www.lemonde.fr/planete/article/2021/02/03/climat-l-etat-condamne-p our-carences-fautives-dans-1-affaire-du-siecle_6068613_3244.html (accessed on 3 September 2021).

173. Klimaatzaak/L'Affaire Climat. Available online: https:/ / www.klimaatzaak.eu/en (accessed on 3 September 2021).

174. Ganguly, G.; Setzer, J.; Heyvaert, V. If at first you don't succeed: Suing corporations for climate change. Oxf. J. Leg. Stud. 2018, 38, 841-868. [CrossRef]

175. Konkes, C. Green lawfare: Environmental public interest litigation and mediatized environmental conflict. Environ. Commun. 2018, 12, 191-203. [CrossRef]

176. Banda, M.L.; Fulton, C.S. Litigating climate change in national courts: Recent trends and developments in global climate law. Environ. Law Report. News Anal. 2017, 47, 10121.

177. Preston, B.J. The contribution of the courts in tackling climate change. J. Environ. Law 2016, 28, 11-17. [CrossRef]

178. Percival, R.V. The "greening" of the global judiciary. J. Land Use Environ. Law 2017, 32, 333-358.

179. Wegener, L. Can the Paris agreement help climate change litigation and vice versa? Transnatl. Environ. Law 2020, 9, 17-36. [CrossRef]

180. Yoshida, K.; Setzer, J. The trends and challenges of climate change litigation and human rights. Eur. Hum. Rights Law Rev. 2020, 2, 140-152.

181. Setzer, J.; Vanhala, L.C. Climate change litigation: A review of research on courts and litigants in climate governance. Clim. Chang. 2019, 10, e580. [CrossRef]

182. Peel, J.; Osofsky, H.M. Climate change litigation: Lessons and pathways. Judic. Off. Bull. 2017, 29, 99-104. Available online: https: / / law.unimelb.edu.au/_data/assets/pdf_file/0020/2608004/December-article-JOB-final-2017.pdf (accessed on 25 May 2021).

183. Peel, J.; Godden, L.; Keenan, R.J. Climate change law in an era of multi-level governance. Transnatl. Environ. Law 2012, 1, 245-280. [CrossRef]

184. Peel, J.; Osofsky, H.M. Climate change litigation. Annu. Rev. Law Soc. Sci. 2020, 16, 21-38. [CrossRef]

185. Peel, J.; Osofsky, H.; Foerster, A. Shaping the next generation of climate change litigation in Australia. Melb. UL Rev. 2017, 41, 793.

186. Osofsky, H.M. The geography of emerging global south climate change litigation. Am. J. Int. Law 2020, 114, 61-66. [CrossRef]

187. Setzer, J.; Benjamin, L. Climate litigation in the Global South: Constraints and innovations. Transnatl. Environ. Law 2020, 9, 77-101. [CrossRef]

188. Sindico, F.; Mbengue, M.M. (Eds.) Comparative Climate Change Litigation: Beyond the Usual Suspects; Springer: Cham, Switzerland, 2020.

189. Nash, R.F. The Rights of Nature: A History of Environmental Ethics; University of Wisconsin Press: Madison, WI, USA, 1989.

190. Cano Pecharroman, L. Rights of nature: Rivers that can stand in Court. Resources 2018, 7, 13. [CrossRef]

191. Kotzé, L.J.; Calzadilla, P.V. Somewhere between rhetoric and reality: Environmental constitutionalism and the rights of nature in Ecuador. Transnatl. Environ. Law 2017, 6, 401-433. [CrossRef] 
192. Camargo, X.S. The ecocentric turn of environmental justice in Colombia. King's Law J. 2019, 30, 1-10. [CrossRef]

193. Boyd, D.R. Recognizing the rights of nature: Lofty rhetoric or legal revolution? Nat. Resour. Environ. 2018, 32, $13-17$.

194. Akchurin, M. Constructing the rights of nature: Constitutional reform, mobilization, and environmental protection in Ecuador. Law Soc. Inq. 2015, 40, 937-968. [CrossRef]

195. Borràs, S. New transitions from human rights to the environment to the rights of nature. Transnatl. Environ. Law 2016, 5, 113-143. [CrossRef]

196. Gellers, J.C. Earth system law and the legal status of non-humans in the Anthropocene. Earth Syst. Gov. 2021, 7, 100083. [CrossRef]

197. Murray, J. Earth jurisprudence, wild law, emergent law: The emerging field of ecology and law-Part 1 and 2. Liverp. Law Rev. 2014, 35, 215-231. [CrossRef]

198. Rühs, N.; Jones, A. The implementation of earth jurisprudence through substantive constitutional rights of nature. Sustainability 2016, 8, 174. [CrossRef]

199. Preston, B. The challenges of approaching judging from an earth centred perspective. ResponsAbility 2018, 35, $218-226$.

200. Brooks, R.O.; Jones, R. Law and Ecology: The Rise of the Ecosystem Regime; Routledge: London, UK, 2017.

201. Weber, M.; Krogman, N.; Antoniuk, T. Cumulative effects assessment: Linking social, ecological, and governance dimensions. Ecol. Soc. 2012, 17, 22. [CrossRef]

202. Weston, B.H.; Bollier, D. Green Governance: Ecological Survival, Human Rights, and the Law of the Commons; Cambridge University Press: Cambridge, UK, 2013.

203. Cullinan, C. Wild Law: A Manifesto for Earth Justice. Moral and Cultural Concerns on the Rights of the Nature; Chelsea Green Publishing: Chelsea, VT, USA, 2011.

204. Humphreys, D. Rights of Pachamama: The emergence of an earth jurisprudence in the Americas. J. Int. Relat. Dev. 2017, 20, 459-484. [CrossRef]

205. Trouwborst, A.; Blackmore, A.; Boitani, L.; Bowman, M.; Caddell, R.; Chapron, G.; Cliquet, A.; Couzens, E.; Epstein, Y.; Fernández-Galiano, E.; et al. International wildlife law: Understanding and enhancing its role in conservation. BioScience 2017, 67, 784-790. [CrossRef]

206. The UN World Charter for Nature. A Code of Conduct for the Protection of Global Nature, Adopted by the General Assembly in its Resolution 37/7 of 10 October 1982. Available online: http:/ / www.un-documents.net/wcn.htm (accessed on 3 September 2021).

207. May, J.R.; Daly, E. Global Environmental Constitutionalism; Cambridge University Press: Cambridge, UK, 2015.

208. Stop Ecocide Foundation. Independent Expert Panel for the Legal Definition of Ecocide. June 2021. Available online: https:/ / static1.squarespace.com/static/5ca2608ab914493c64ef1f6d/t/60d7479cf8e7e5461534dd07/1624721314430/SE+Foun dation+Commentary+and+core+text+revised+\%281\%29.pdf (accessed on 3 September 2021).

209. Supreme Court of India. Asiatic Lions had a Right to Life. Centre for Environmental Law, WWF-I v Union of India [2013] INSC 427. 2013. Available online: https://indiankanoon.org/doc/27900105/?_cf_chl_jschl_tk_=pmd_Jg8BzLIUds3ebfLUYR2X4 uUzMJGtF.jyF_UtPzGuJGA-1632074996-0-gqNtZGzNAiWjcnBszQjR (accessed on 3 September 2021).

210. Uttaranchal High Court, India, Lalit Miglani vs State of Uttarakhand And Others on 30 March, 2017. Available online: https: / / indiankanoon.org/doc/92201770/ (accessed on 3 September 2021).

211. Supreme Court of Justice, Colombia STC 4360/18. Available online: https:/ / cortesuprema.gov.co/corte/wp-content/uploads/2 018/04/STC4360-2018-2018-00319-011.pdf (accessed on 3 September 2021).

212. Constitutional Court of Colombia: T 622/2016. Available online: https://www.corteconstitucional.gov.co/relatoria/2016/t-62216.htm (accessed on 3 September 2021).

213. EACJ, ANAW V Tanzania. (Ref: 9/2010). The Serengeti National Park, is a "World Heritage Property" (UNESCO). Available online: https: / / www.eacj.org/?cases=african-network-animal-welfare-anaw-vs-attorney-general-united-republic-tanzania (accessed on 3 September 2021).

214. Vera, L.A.; Walker, D.; Murphy, M.; Mansfield, B.; Siad, L.M.; Ogden, J.; EDGI. When data justice and environmental justice meet: Formulating a response to extractive logic through environmental data justice. Inf. Commun. Soc. 2019, 22, 1012-1028. [CrossRef] [PubMed]

215. Humphreys, S. Climate justice: The claim of the past. J. Hum. Rights Environ. 2014, 5, 134. [CrossRef]

216. Humphreys, S.; Otomo, Y. Theorising international environmental law. In The Oxford Handbook of International Legal Theory; Hoffmann, F., Orford, A., Eds.; Oxford University Press: Oxford, UK, 2014.

217. Garmendia, E.; Urkidi, L.; Arto, I.; Barcena, I.; Bermejo, R.; Hoyos, D.; Lago, R. Tracing the impacts of a northern open economy on the global environment. Ecol. Econ. 2016, 126, 169-181. [CrossRef]

218. Bhattarai, A.M. Earthquake and earth justice: Emergence of the environmental justice movement and its relevance in addressing unanticipated events. In Living Under the Threat of Earthquakes; Springer: Cham, Switzerland, 2018; pp. $285-292$.

219. Dutfield, G. TK unlimited: The emerging but incoherent international law of traditional knowledge protection. J. World Intellect Prop. 2017, 20, 144-159. [CrossRef]

220. Aoki, K. Neocolonialism, anticommons property, and biopiracy in the (not-so-brave) new world order of international intellectual property protection. In Globalization and Intellectual Property; Routledge: London, UK, 2017; pp. 195-242.

221. Altwicker-Hámori, S.; Altwicker, T.; Peters, A. Measuring violations of human rights: An empirical analysis of awards in respect of non-pecuniary damage under the European Convention on Human Rights. Z. Ausländisches Offentl. Recht Völkerrecht (ZaöRV)/Heidelb. J. Int. Law (HJIL) 2016, 76, 1-51. [CrossRef] 
222. Zerk, J. Corporate Liability for Gross Human Rights Abuses: Towards a Fairer and More Effective System of Domestic Law Remedies; Office of the United Nations High Commissioner for Human Rights (OHCHR): Geneva, Switzerland, 2014.

223. African Commission on Human and Peoples' Rights v. Republic of Kenya, Appl. No. 006/2012, Judgment of 26 May 2017. Available online: https://www.escr-net.org/caselaw/2017/african-commission-human-and-peoples-rights-v-republic-kenya -acthpr-application-no (accessed on 3 September 2021).

224. Colombian Constitutional Court, Judgement T019/19. Available online: https://www.corteconstitucional.gov.co/english/ (accessed on 3 September 2021).

225. Global Issues. Evictions Provoked by a the Reforestation Project in the Park, Jointly Run by The Netherlands-Based FACE Foundation and the Uganda Wildlife Authority. Global Issues, 13 November 2009. Available online: https://www.globalissues.o $\mathrm{rg} /$ news/2009/11/13/3491 (accessed on 3 September 2021).

226. India Ecology vs Indigenous Communities: Wildlife First \& Ors. versus Ministry of Forest and Environment. Process of Eviction of Scheduled Tribes (STs) and Other Traditional Forest Dwellers. Available online: https://www.livelaw.in/pdf_upload/pdf_up load-358658.pdf (accessed on 3 September 2021).

227. Tyson, B. An empirical analysis of sue-and-settle in environmental litigation. Va. Law Rev. 2014, 100, $1545-1601$.

228. Council of Europe. European Convention on Human Rights; Council of Europe: Strasbourg, France, 1950.

229. International Commission of Jurists (ICJ). The Right to a Remedy and Reparation for Gross Human Rights Violations A Practitioners' Guide; International Commission of Jurists (ICJ): Geneva, Switzerland, 2018; Available online: https://www.icj.org/wp-conte nt/uploads/2018/11/Universal-Right-to-a-Remedy-Publications-Reports-Practitioners-Guides-2018-ENG.pdf (accessed on 3 September 2021).

230. Shelton, D. Remedies in International Human Rights Law; Oxford University Press: Oxford, UK, 2015.

231. Hansen, G.; Stone, D.; Auffhammer, M.; Huggel, C.; Cramer, W. Linking local impacts to changes in climate: A guide to attribution. Reg. Environ. Chang. 2016, 16, 527-541. [CrossRef]

232. Heede, R. Tracing anthropogenic carbon dioxide and methane emissions to fossil fuel and cement producers, 1854-2010. Clim. Chang. 2014, 122, 229-241. [CrossRef]

233. Zhang, W.; Wang, F.; Hubacek, K.; Liu, Y.; Wang, J.; Feng, K.; Jiang, L.; Jiang, H.; Zhang, B.; Bi, J. Unequal exchange of air pollution and economic benefits embodied in China's exports. Environ. Sci. Technol. 2018, 52, 3888-3898. [CrossRef]

234. Kagawa, S.; Suh, S.; Hubacek, K.; Wiedmann, T.; Nansai, K.; Minx, J. $\mathrm{CO}_{2}$ emission clusters within global supply chain networks: Implications for climate change mitigation. Glob. Environ. Chang. 2015, 35, 486-496. [CrossRef]

235. Wiedmann, T.O.; Schandl, H.; Lenzen, M.; Moran, D.; Suh, S.; West, J.; Kanemoto, K. The material footprint of nations. Proc. Natl. Acad. Sci. USA 2015, 112, 6271-6276. [CrossRef] 